\title{
SCHEMATY EKUMENY W LITERATURZE PATRYSTYCZNEJ W KONTEKŚCIE KLASYCZNYCH SCHEMATÓW ZAMIESZKAŁEJ ZIEMI ${ }^{*}$
}

Zagadnienie historii geo- i kartografii w pismach Ojców Kościoła nie jest zbyt często podejmowane w literaturze przedmiotu ${ }^{1}$. Jeszcze rzadziej poruszany jest wielowątkowy $i$ interdyscyplinarny temat schematyzacji w geografii patrystycznej ${ }^{2}$. Ze względu na ów złożony charakter tego zagadnienia zo-

" Wykaz zastosowanych niepatrystycznych skrótów: FEK - Die Fragmente des Eudoksos von Knidos (ed. F. Lasserre); FGrHist - Die Fragmente der Griechischen Historiker (ed. F. Jacoby); FHG - Fragmenta Historicorum Graecorum (ed. C. Müller); FVS - Die Fragmente der Vorsokratiker (ed. H. Diels); GFE - Die Geographischen Fragmente des Erathostenes (ed. H. Berger); GGM Geographi Graeci Minores; MGH SRG - Monumenta Germaniae Historica. Scriptores Rerum Germanicarum; Nobbe - Ptolemaeus, Geographia (ed. C.F.A. Nobbe); Theiler - Posidonios, Die Fragmente (ed. H. Theiler); Wehrli - Die Schule von Aristoteles. Texte und Kommentare, Heft 1: Dikaiarchos (ed. F. Wehrli).

${ }^{1}$ Do najważniejszych pozycji z zakresu historii geografii patrystycznej należą: G. Marinelli, $L a$ geografia e i Padri della Chiesa, „Bollettino della Società Geografica Italiana” 16 (1882) 472-498, 532-573 = tenże, Scritti minori, vol. 1: Metodo e la storia della geografia, Firenze 1908, 281-383 = thum. niemieckie L. Neumann: Die Erdkunde bei den Kirchenvätern, Leipzig 1884; K. Holzhey, Das Bild der Erde bei den Kirchenvätern, w: Festgabe Alois Knöpfler zur Vollendung des 70. Lebensjahres gewidmet von seinen Freunden und Schülern, hrsg. H.M. Gielt - G. Pfeilschifter, Freiburg im Breisgau 1917, 177-187; F. Gisinger, Oikumene, RE XVII 2, Stuttgart 1937, 2160-2164; R.M. Grant, Patristica, VigCh 3 (1949) 225-229; W. Wolska, La Topographie Chrétienne de Cosmas Indicopleustès. Théologie et sciences au VI' siècle, Paris 1962; taż, Geographie (thum. J. Engemann), RACh 10, 173-218; R.M. Grant, Early christian Geography, VigCh 46 (1992) 105-111; M. Sechi Nuvole, Descrizioni e rappresentazioni dell'ecumene nella geografia cristiana, w: L'Africa romana. Atti dell'XI Convegno di Studio (Cartagine, 15-18 dicembre 1994), ed. M. Khanoussi - P. Ruggeri - C. Vismara, vol. 1, Sassari 1996, 361-383; J. Koder, Die räumlichen Vorstellungen der Byzantiner von der Ökumene (4. bis 12. Jahrhundert), „Anzeiger der Philosophisch-Historischen Klasse der Österreichischen Akademie der Wissenschaften” 137 (2002) nr 2, 15-34; tenże, „Euromediterraneum” $i$ „Euroazja” w pogladach Bizantyńczyków na przestrzeń i politykę, Labarum 4, Poznań 2007. Pewne wybiórcze informacje z tego zakresu zawierają rzecz jasna syntezy dotyczące geo- i kartografii późno-antycznej i średniowiecznej, por. niżej przyp. 96-97.

2 Jako instruktywne wprowadzenie $\mathrm{w}$ ten blok zagadnień można potraktować artykuły U. Lindgren, Schematische Zeichnungen in der Geographie der Antike und des Mittelalters, w: Mathemata. Festschrift für Helmut Gericke, hrsg. M. Folkers - U. Lindgren, Wiesbaden - Stuttgart 
stanie ono w niniejszym opracowaniu ograniczone wyłącznie do schematów

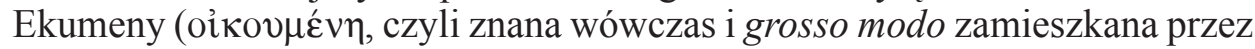
ludzi część ziemi), co pozwoli pominąć schematy szczegółowe, odnoszące się do poszczególnych krain lub do konkretnych miejsc. Ponieważ zaś patrystyczne schematy Ekumeny wyrosły ze schematów stosowanych powszechnie w geo- i kartograficznej literaturze grecko-rzymskiej, należy je rozpatrywać w kontekście tych właśnie klasycznych schematów „ekumenicznych”.

Aby głębiej wniknąć w istotę przedmiotu niniejszych analiz, warto odwołać się do ducha języka greckiego i uświadomić sobie wagę podstawowego rozróżnienia między pojęciami geografia $(\gamma \varepsilon \omega \gamma \rho \alpha \varphi i ́ \alpha)$ i geometria $(\gamma \varepsilon \omega \mu \varepsilon$ $\left.\tau \operatorname{cí}^{3}\right)^{3}$, odnoszącymi się do badania powierzchni ziemi $(\gamma \hat{\eta})$. Pierwsze z nich akcentuje aspekt opisowy tych dociekań ( $\gamma \rho \alpha ́$ ó $\omega$ - opisuję, przedstawiam, piszę), drugie natomiast aspekt matematyczny, odwołując się do pomiarów $(\mu \varepsilon \tau \rho \varepsilon ́ \omega-$ mierzę). Warto również przypomnieć, że starożytni obok terminu $\gamma \varepsilon \omega \gamma \rho \alpha \varphi \hat{i} \alpha$ posługiwali się jeszcze dwoma pokrewnymi pojęciami, odnoszącymi się do opisu przestrzeni, których zakresy nie zawsze dają się jed-

1985, 69-82; taż, Eine Abstraktion des Weltbildes. Schemakarten, „Geschichte in Wissenschaft und Unterricht” 36 (1987) 23-32; por. też GFE, s. 332-334; H. Butzer, Über Strabos Geographica, insbesondere über Plan und Ausführung des Werkes und Strabos Stellung zu seinen Vorgängern, Frankfurt am Main 1887, 16-17; K. Miller, Mappaemundi. Die ältesten Weltkarten, VI: Rekonstruierte Karten, Stuttgart 1898, 119-120; J. Röger, Die Geländedarstellung auf Karten: eine entwicklungsgeschichtliche Studie, München 1908, passim; tenże, Die Bergzeichnung auf den älteren Karten: ihr Verhältnis zur darstellenden Kunst, München 1910, passim; G. Aujac, Greek Cartography in the Early Roman World, w: The History of Cartography, vol. 1: Cartography in Prehistoric, Ancient, and Medieval Europe and the Mediterranean, ed. J.C. Harley - D. Woodward, Chicago - London 1987, 174-175; O.A. Dilke, Itineraries and Geographical Maps in the Early and Late Roman Empires, w: The History of Cartography, vol. 1, s. 243; Sechi Nuvole, Descrizioni e rappresentazioni dell'ecumene nella geografia cristiana, s. 365; H. Kugler, Imago mundi: Kartographische Skizze und literarische Beschreibung, w: Mediëvistische Komparatistik. Festschrift für Franz J. Worstbrock zum 60. Geburtstag, hrsg. W. Harms - J.D. Müller, Stuttgart 1997, 82-83; H.J. Gehrke, Die Geburt der Erdkunde aus dem Geist der Geometrie. Überlegungen zur Entstehung und zur Frühgeschichte der wissenschaftlichen Geographie bei den Griechen, w: Gattungen wissenschaftlicher Literatur in der Antike, hrsg. W. Kullmann - J. Althoff - M. Asper, Tübingen 1998, 181-182. W literaturze polskiej tę szczegółową kwestię podejmowali swego czasu m.in.: B. Gustawicz, Zarys historyczny sposobów kreślenia kart geograficznych, w: Sprawozdanie dyrektora C. K. Gimnazyum Nowodworskiego św. Anny w Krakowie za rok szkolny 1882, Kraków 1882, 5 [Odbitka: Kraków 1882, 5]; J. Staszewski, Środowisko geograficzne w nauce antycznej, ,Zeszyty Geograficzne Wyższej Szkoły Pedagogicznej w Gdańsku” 2 (1960) 37; P. Kochanek, Die Vorstellung vom Norden und der Eurozentrismus. Eine Auswertung der patristischen und mittelalterlichen Literatur, Mainz 2004, s. 161-162, przyp. 1; s. 03, przyp. 541; s. 356, przyp. 145; s. 378, przyp. 255; zob. też F. Bujak, Geografia na Uniwersytecie Jagiellońskim do połowy XVI wieku, w: Księga Pamiątkowa uczniów Uniwersytetu Jagiellońskiego, Kraków 1900, 75 = tenże, Studia geograficzno-historyczne, Warszawa - Kraków 1925, 35.

${ }^{3}$ Za twórcę terminu technicznego $\gamma \varepsilon \omega \gamma \rho \alpha \varphi i ́ \alpha$ uchodzi Eratostenes. Natomiast pojęcie $\gamma \varepsilon \omega$ $\mu \varepsilon \tau$ ๆ́́ $\alpha$ poświadczone jest już w Chmurach Arystofanesa (ok. 446-385 prz. Chr.), por. F. Lasserre, Geographie, w: Der Kleine Pauly, Bd. 2, München 1967, 751 i 754. 
noznacznie rozdzielić. Są to pojęcia chorografia $(\chi \omega \rho \circ \gamma \rho \alpha \varphi$ í $\alpha)$ i topografia

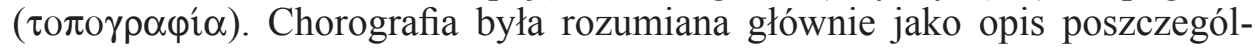
nych regionów ( $\chi \hat{\omega} \rho \varsigma)$. Topografia natomiast to przedstawienie konkretnych niewielkich obszarów lub miejsc ( $\tau$ ó $\pi$ os). W konsekwencji należy traktować choro- i topografię jako części składowe geografii jako takiej. Ponieważ zarówno antyczna geografia, jak i chorografia oraz topografia zajmowały się opisem ( $\gamma \varepsilon \omega-\gamma \rho \alpha \varphi i \alpha, \chi \omega \rho o-\gamma \rho \alpha \varphi i \alpha, \tau o \pi 0-\gamma \rho \alpha \varphi i \alpha)$ bądź ziemi jako takiej, bądź jej części, można je traktować jako pojęcia humanistyczne w dzisiejszym tego słowa znaczeniu. Natomiast antyczna geometria należy bez wątpienia do współczesnych nauk ścisłych. Jednak zarówno geografia, jak i geometria mają wspólny przedmiot swych dociekań, którym jest ziemia, i stanowią w tym sensie dwa aspekty tego, co etymologicznie dobrze oddaje anachroniczny w tym

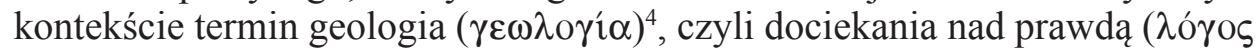
jako przeciwieństwo $\mu \hat{v} \theta$ os - mit) o ziemi lub nad jej istotą.

W kontekście niniejszego opracowania czasowniki „opisuję” ( $\gamma \rho \alpha ́(\varphi \omega)$

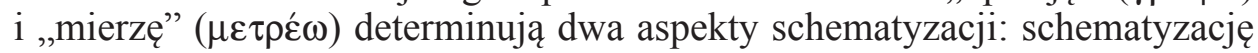
geograficzną (oraz chorograficzną i topograficzną) oraz schematyzację geometryczną. Pierwsza z nich jako opisowa, zakłada pewną swobodą w doborze schematów i ich związek z tzw. „życiem”. Druga natomiast suponuje schematy, które winien cechować pewien matematyczny rygoryzm.

W ważnym dla poniższych rozważań kontekście, pojęcie geografia wraz $z$ terminem schemat $(\sigma \chi \hat{\eta} \mu \alpha)$ pojawia się u Strabona (63 prz. Chr.-24 po Chr.). Tenże geograf z Amazji pisze mianowicie, że morze $(\theta \alpha ́ \lambda \alpha \sigma \sigma \alpha)$ jest głównym żywiołem, który opisuje ziemię ( $\gamma \varepsilon \omega \gamma \rho \alpha \varphi \varepsilon \hat{\imath})$, i który nadaje jej kształt $(\sigma \chi \eta \mu \alpha \tau i \zeta \varepsilon \imath)$, tworząc zarówno zatoki, konkretne akweny morskie oraz cieśniny, jak i przesmyki, półwyspy i przylądki; w działaniu tym współpracują z morzem rzeki i góry ${ }^{5}$. Strabon sięgnął zatem jednoznacznie do etymolo-

\footnotetext{
${ }^{4}$ Terminu tego w sensie zbliżonym do współczesnego znaczenia tego słowa użył po raz pierwszy Jean-André de Luc (1727-1817), szwajcarski geolog i meteorolog (czasem pisownia jego nazwiska brzmi: Deluc), por. J.A. de Luc, Lettres physiques et morales sur les montagnes et sur l'histoire de la terre et de l'homme, La Haye 1778, s. VII-VIII, przyp. (a): „Je n'entends ici par Cosmologie que la connoissance de la Terre, \& non celle de l'Univers. Dans ce sens, Geologie eût été le mot propre; mais n'ose m'en servir, parce qu'il n'est pas usité. J'employerai donc toujours ce mot Cosmologie, dans le sens que je viens de définir, \& par analogie à Cosmographie, \& à Cosmopolite surtout, dont on ne se fert que relativement à la Terre" (praca ta jest w całości dostępna w internecie: http://cyber.bu.ubordeaux1.fr/ouvrages/montagne/index.html [sprawdzono: 1.05.2011]) Jednak terminem technicznym sensu stricto, który obowiązuje do dziś, uczynił to pojęcie jego rodak Horace-Bénédict de Saussure (1740-1799). Użył go on w Discours préliminaire, czyli we wprowadzeniu do swego dzieła Voyages dans les Alpes, précédés d'un essai sur l'histoire naturelle des environs de Genève, t. 1, Neuchâtel 1779 [repr.: Genève 1978]; por. D.R. Dean, The Word 'Geology', „Annals of Science” 36 (1979) 35-43.

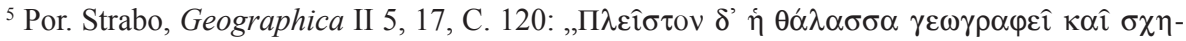

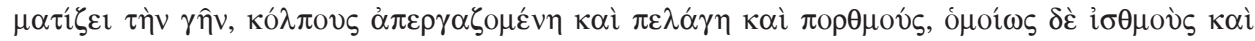

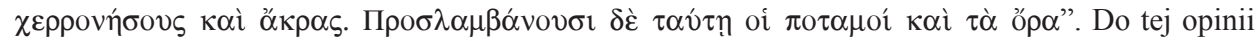
odwołują się na gruncie polskim m.in.: B. Biliński, De Graeciae in Pliniana descriptione (N.H. IV
} 
gii pojęcia geografia i zdefiniował je jako opis ziemi, dokonywany poprzez opis jej kształtów. Za tworzenie owych kształtów odpowiadają morze, góry i rzeki. W ten sposób została oddana istota greckiego terminu $\gamma \varepsilon \omega \gamma \rho \alpha \varphi i \alpha$. Powyższe stanowisko Strabona wydaje się być pod silnym wpływem antycznej nawigacji. Jest to niemalże punkt widzenia sternika, odpowiedzialnego za bezpieczne doprowadzenie statku do portu przeznaczenia. To obraz ziemi, opisany (czy też malowany słowami) przez człowieka morza, który zatoki, cieśniny, przylądki, półwyspy, góry, czy ujścia rzek traktuje z jednej strony jako punkty orientacyjne, z drugiej zaś jako miejsce zagrożenia lub bezpiecznego schronienia. W tym sensie opis ziemi staje się głównie opisem kształtów (= schematów) linii brzegowej ${ }^{6}$, czyli swoistą mnemotechniczną mapą morską - portolaną, której literackim echem był periplus ( $\pi \varepsilon \rho i ́ \pi \lambda \circ \nu \varsigma$ ), rozumiany jako wieloaspektowa relacja z opłynięcia danego akwenu morskiego. W konsekwencji tak pojętą geografię można zredukować prawie wyłącznie do opisu owych kształtów linii brzegowej i określić terminem $\sigma \chi \eta \mu \alpha \tau \imath \sigma \mu{ }^{\circ} \varsigma^{7}$. Kształty te należało zapamiętać tak, jak Symonides z Keos (ok. 556-468 prz. Chr.) ojciec greckiej mnemotechniki - zapamiętał rozmieszczenie biesiadników przy owej nieszczęsnej uczcie, od której miała wziąc początek grecka technika zapamiętywania. Oto poeta ów brał udział w pewnej biesiadzie, wydanej na cześć zwycięskiego zapaśnika. W trakcie uczty musiał jednak chwilowo opuścić towarzystwo. W tym czasie runął dach budynku i wszyscy uczestnicy bankietu zginęli, przy czym ich ciała zostały zmasakrowane, co nie pozwalało na identyfikację zwłok. Cudem ocalały Symonides był jednak w stanie odtworzyć z pamięci rozmieszczenie biesiadników przy stole i na tej podstawie

\footnotetext{
1-32) sinibus quaestiones, „Eos” 41 (1940-1946) fasc. 1, 123; Staszewski, Środowisko geograficzne w nauce antycznej, s. 37.

${ }^{6} \mathrm{~W}$ tym aspekcie w polskiej bibliografii przedmiotu warto zwrócić uwagę na następujące prace: S. Mielczarski, Opis brzegu morskiego w praktyce dawnych żeglarzy, w: Problemy nauk pomocniczych historii, III: Materiały z III konferencji poświęconej naukom pomocniczym historii (Katowice - Wisła, 29-31 V 1974), Katowice 1974, 119-127; S. Ducin, Sztuka nawigacji w Rzymie w okresie republiki, w: Morze w kulturze starożytnych Greków i Rzymian, red. J. Roztropowicz, Opole 1995, 223-227; tenże, Sztuka nawigacji w starożytnej Grecji i w Rzymie, Lublin 1997, $123-$ 133; tenże, Żegluga grecka, w: Wielka Historia Świata, t. 3: 600-330, red. M. Szulc, Kraków 2001, 80-81; F. Bujak, O średniowiecznych mapach żeglarskich, „Rozprawy Wydziału HistorycznoFilozoficznego Akademii Umiejętności” 46 (1903) 190-264 (= tenże, Studia geograficzno-historyczne, s. 149-230); W. Iwańczak, Mapy morskie i ich tajemnice, „Mówią Wieki” 36 (1993) nr 1(404), 19-24; tenże, Wybrane zagadnienia wyobraźni kartograficznej średniowiecza, w: Wyobraźnia średniowieczna, red. T. Michałowska, Warszawa 1996, 105-106.

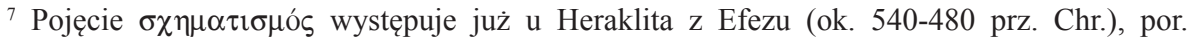
Herakleitos, F 12 A 1, w: FVS, vol. 1, s. 69, 26; zob. też Posidonius Apamensis, F 78 (53, 7), w: Theiler, t. 1, s. 81 (= Diodorus Siculus, Bibliotheca II 53, 7); Ptolemaeus, Geographia II 1, 2, Nobbe I, s. 61, 19; tamże II 1, 9, Nobbe I, s. 63, 18.
} 
zidentyfikowano ciała ofiar ${ }^{8}$. Zatem u podstaw starożytnej mnemotechniki leżała swoista „geografia”, czy raczej „topografia” pewnej uczty.

Starożytność znała jednak nie tylko opis ziemi ( $\gamma \varepsilon \omega \gamma \rho \alpha \varphi i ́ \alpha)$, lecz również jej pomiar $\left(\gamma \varepsilon \omega \mu \varepsilon \tau \rho^{\prime} \alpha\right)$. Na podstawie pomiaru przypisywano również określone kształty konkretnych figur geometrycznych, czyli schematy geometryczne, zarówno ziemi jako takiej, jak i jej poszczególnym obszarom ${ }^{9}$. Jednak schematy geometryczne, w przeciwieństwie do schematów geograficznych, nie odnosiły się głównie do linii brzegowej, lecz to powierzchni ziemi, traktowanej jako Ekumena.

Należy też zwrócić uwagę na fakt, że geografia starożytna i średniowieczna ${ }^{10}$ nie była nigdy samodzielną dyscypliną w dzisiejszym tego słowa znaczeniu. Była ona zawsze związana z tym, co dziś nazywamy etnografią, historiografią, astronomią, teologią, czy filozofią. Schematy geograficzne (w znacznie mniejszym stopniu odnosi się to do schematów geometrycznych) starożytnych nie były zatem nigdy „,czyste”, lecz stanowiły część szerszego kontekstu. W konsekwencji odczytanie danego schematu staje się wypadkową wszechstronnej analizy treści źródła, w którym jest on zawarty. Nie należy również zapominać o gatunku literackim, w którym znajduje się dany opis. Pochodną tego stanu rzeczy są wyobrażenia kartograficzne, powstające dziś na podstawie tych antycznych narracji, bądź też wyobrażenia średniowieczne, które dotrwały do naszych czasów.

Idąc za Posejdoniuszem z Apamei (ok. 135-50 prz. Chr.) Agatemerus, piszący w III wieku po Chr., przedstawił w swej Geographiae informatio zwię-

${ }^{8}$ Opis ten znajduje się w: Cicero, De oratore II 352-353; Quintilianus, Institutio oratoria XI 2, 11-13, por. H. Blum, Die antike Mnemotechnik, Hildesheim 1969, 41-46; S. Goldmann, Statt Totenklage Gedächnis. Zur Erfindung der Mnemotechnik durch Simonides von Keos, „Poetica” 21 (1989) fasc. 1-2, 43-66; M. Frenschkowski, Offenbarung und Epiphanie, Bd. 2: Die verborgene Epiphanie in Spätantike und frühen Christentum, Tübingen 1997, 100; A. Gormans, Geometria et ars memorativa. Studien zur Bedeutung von Kreis und Quadrat als Bestandteile mittelalterlicher Mnemonik und ihrer Wirkungsgeschichte an ausgewählten Beispielen, Doktorarbeit, Aachen 1999, 20 (praca ta jest w całości dostępna w internecie pod adresem: http://darwin.bth.rwth-aachen.de/ opus3/volltexte/2003/551/pdf/Gormans_Andreas/pdf [sprawdzono: 1.05.2011]); zob też S. Brud, Mnemotechnika w Rzymie w I w. przed Chrystusem, „Meander” 54 (1999) nr 2, 147.

${ }^{9}$ Por. Strabo, Geographica II 1, 30, C. 83.

${ }^{10} \mathrm{~W}$ literaturze polskiej kwestię stosunku geografii do geometrii w dobie średniowiecza podnosił wielokrotnie J. Strzelczyk: Gerwazy z Tilbury. Studium z dziejów uczoności geograficznej w średniowieczu, Wrocław - Warszawa 1970, 7; tenże, Odkrywanie Polski przez Europę, w: Polska dzielnicowa i zjednoczona: państwo, społeczeństwo, kultura, red. A. Gieysztor, Warszawa 1972, 55; tenże, Uwagi o kartografii średniowiecznej, w: Problemy nauk pomocniczych historii, III, s. 114 (= tenże, Średniowieczny obraz świata, Poznań 2004, 61-62); tenże, Drogi i bezdroża wiedzy o świecie w Europie wczesnośredniowiecznej. Aethicus z Istrii i jego Kosmografia, „Kwartalnik Historyczny” 100 (1993) nr 4, 5 (= tenże, Średniowieczny obraz świata, s. 65); tenże, ,Klucz do poznania nieba". Z dziejów myśli racjonalistycznej w średniowieczu, Gdańsk 2003, 32; tenże, Mapa w średniowieczu. Uwagi o stanie badań i średniowiecznym pojmowaniu map, w: Ad fontes. O naturze źródła historycznego, red. S. Rosik - P. Wiszewski, Wrocław 2004, 118. 
zły, bo kilkuzdaniowy zarys historii greckiej schematyzacji Ekumeny, który składa się niejako z sześciu epok: 1. niewymienieni imiennie najdawniejsi badacze tego zagadnienia mieli charakteryzować zamieszkałą ziemię przymiotnikiem $\sigma \tau \rho \circ \gamma \gamma u ́ \lambda \eta$, czyli jako „mającą kształt okręgu”. W jego środku miała być położona Grecja, której centrum stanowiły Delfy; 2. Demokryt z Abdery (ok. 470-370 prz. Chr.) miał być pierwszym Grekiem, który twier-

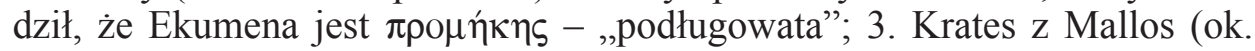
214-150 prz. Chr.) dowodził natomiast, że swym kształtem przypomina ona

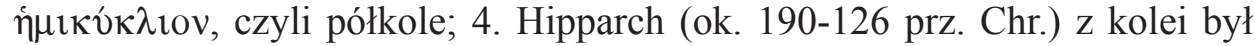

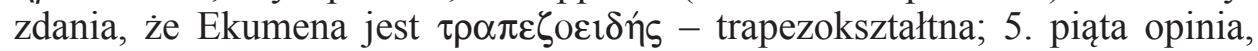
której autorów Agatemerus nie podał, głosiła, że Ekumena jest oủpoeıðń czyli przypomina swym kształtem ogon lub kitę; 6. szósty i ostatni schemat Ekumeny, który porównuje jej kształt do (łoża) procy ( $\sigma \varphi \varepsilon v \delta o v o \varepsilon ı \delta \eta ́ \varsigma)$, miał być autorstwa samego Posejdoniusza ${ }^{11}$.

Pierwszy wspomniany wyżej schemat zamieszkałej ziemi w geografii greckiej jest uchwytny już w dziele Homera (VIII w. prz. Chr.). Jego opis tarczy Achillesa przedstawia Ekumenę w formie okręgu otoczonego oceanem (por. rys. 1A) ${ }^{12}$. Podobnego zdania był Anaksymander (ok. 610-546 prz.

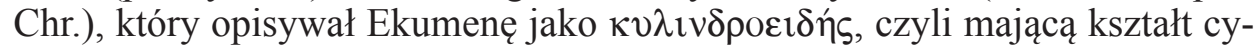
lindryczny ${ }^{13}$. Co to dokładnie oznacza, wyjaśnił tenże sam mędrzec pisząc, że widziana horyzontalnie Ekumena ma schemat okręgu ( $\gamma$ $\rho \operatorname{có}$ ), czyli ma kształt kolisty $(\sigma \tau \rho \circ \gamma \gamma \tilde{\lambda} \lambda \mathrm{ov})$. Natomiast widziana wertykalnie przypomina kamienną kolumnę (kíovı $\lambda i ́ \theta \omega \iota \pi \alpha \rho \alpha \pi \lambda \eta ́ \sigma ı v){ }^{14}$. Również Hekatajos z Miletu (ok. 560-480 prz. Chr.) opowiadał się prawdopodobnie za kolistym kształtem Ekumeny ${ }^{15}$. Podobne tezy głosili Anaksagoras (ok. 500-428 prz.

${ }^{11}$ Por. Posidonius Apamensis, F 68a, w: Theiler, t. 1, s. 71-72 (= 87 F 98a, w: FGrHist, II/A, s. 281, 1-3. 5-7 = FHG II F 54, s. 251[col. B] + FHG III F 69, s. 283[col. A] = Agathemerus, Geographiae informatio I 2, GGM II, s. 471, 10-14. 17-21); zob. Scholia ad Dionysium [Prologus], GGM II, s. 428(col. A), 10-12. Autor scholiów do dzieła Dionizjusza Periegety podaje także, że

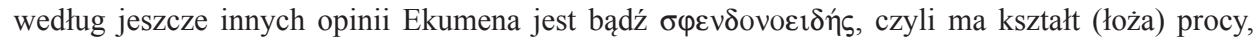

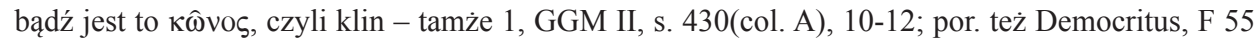
B 15(393), w: FVS, vol. 2, s. 65, 31-33; Eudoxus Cnidaeus, F 276 a (80), w: FEK, s. 97, 29-31; Dikaiarchos, F 109, w: Wehrli, s. 35, 28-31.

${ }^{12}$ Por. Homerus, Ilias XVIII 468-608. Problemem obrazu świata, przedstawionego w opisie tarczy Achillesa, zajmuje się praktycznie każda synteza, która dotyczy historii geografii greckorzymskiej. Istnieją też opracowania monograficzne, poświęcone temu zagadnieniu, por. Ph.R. Hardie, Imago mundi: cosmological and ideological aspects of the shield of Achilles, „Journal of Hellenic Studies" 105 (1985) 11-31; Ph.J. Lee, The shield of Achilles: a vision of the Homeric World, Dalhousie University 1988, passim [non vidi]; A.L. Giesecke, Mapping Utopia: Homer's politics and the birth of the Polis, „College Literature” 34 (2007) 194-214.

${ }^{13}$ Por. Anaximandros, F 2, 10, w: FVS, vol. 1, s. 16, 15-16.

${ }^{14}$ Por. tenże, F 11, 3, w: FVS, vol. 1, s. 16, 32-33; tenże, F 25, w: FVS, vol. 1, s. $20,14$.

${ }^{15}$ Por. Hecataeus Milesius, 1 F 33b, w: FGrHist, I/A, s. 16, 17-19 (= FHG I F 1, s. 1 [col. A] = Herodotus, Historia IV 36); zob. Hecataeus Milesius, 1 T 12, w: FGrHist, I/A, s. 3, 12-13 (= 
Chr.) ${ }^{16}$, Diogenes z Apollonii (V w. prz. Chr.) $)^{17}$ i Leucyp (V w. prz. Chr.) ${ }^{18}$. Taki kształt zamieszkałej ziemi suponował $\mathrm{z}$ jednej strony istnienie centrum, $\mathrm{z}$ drugiej zaś jasno określonych osi symetrii ${ }^{19}$. Schemat ten stanowił zatem najprostszą formę geometryzacji przestrzeni, stając się łatwym do zapamiętania obrazem świata. Być może właśnie dlatego, pomimo że już w starożytności był on mocno krytykowany ${ }^{20}$, nie został definitywnie porzucony ani wówczas, ani później.

Według drugiego schematu Ekumena jest $\pi \rho \mu_{1} \kappa \eta \varsigma$, czyli ma kształt podłużny. Kreślenie to samo w sobie daje bardzo niejasne pojęcie o schemacie, jaki miał przed swymi oczami myśliciel z Abdery. Dopiero stwierdzenie Demokryta, że długość zamieszkałej ziemi na osi wschód-zachód jest półtora razy większa od jej szerokości na osi północ-południe ${ }^{21}$, uświadamia czytelnikowi, że chodzi o rodzaj czworoboku ( $\tau \varepsilon \tau \rho \alpha ́ x \lambda \lambda \varepsilon v \rho o v)$, a dokładnie o równoległobok ( $\pi \alpha \rho \alpha \lambda \lambda \eta \lambda$ ó $\gamma \rho \alpha \mu \mathrm{ov}) \mathrm{w}$ formie prostokąta. Po tej samej linii poszedł Eudoksos z Knidos (410/408-355/347 prz. Chr.), który jednak zdefiniował stosunek długości do szerokości ziemi jak 2:122. Efor z Kyme (ok. 400-330 prz. Chr.), którego równoległoboczny schemat Ekumeny przeszedł do historii

Agathemerus, Geographiae informatio I 1, GGM II, s. 471, 3-4); Hecataeus Milesius, 1 F 36a, w: FGrHist, I/A, s. 16, 12-14 (= Posidonius Apamensis, F 68a, w: Theiler, t. 1, s. $71=$ tenże, 87 F 98a, w: FGrHist, II/A, s. 281, 1-2 = Agathemerus, Geographiae informatio I 2, GGM II, s. 471, 1214 = Scholia ad Dionysium [Prologus], GGM II, s. 428(col. A), 10); por. też Hecataeus Milesius, $1 \mathrm{~F}$ 18a, w: FGrHist, I/A, s. 11, 4-6 (= tenże, 1 F 302c, w: FGrHist, I/A, s. 40, 15-17 = tenże, FHG I F 187, s. 13 [col. A]; I F 278, s. 19 [col. B]; I F 339, s. 26 [col. B] = Hecataeus Abderites, w: FHG II F 11, s. 389 [col. B] = Scholia in Apollonii Argonautica IV 259 [w: Apollonius, Argonautica, emendavit R. Merkel, Scholia vetera e codice Laurentiano, ed. H. Keil, Lipsiae 1854, 493, 20-22]).

${ }^{16}$ Por. Anaxagoras, F 46 A 1, w: FVS, vol. 1, s. 375, 32-33; tenże, F 46 A 42, w: FVS, vol. 1, s. 384, 35; tenże, F 46 A 47, w: FVS, vol. 1, s. 387, 28-29; tenże, F 46 A 87, w: FVS, vol. 1, s. 394, 5-6. Dla niego Ekumena była $\pi \lambda \alpha \tau \varepsilon i \hat{\alpha}$ i $\sigma \tau \rho о \gamma \gamma \hat{\lambda} \lambda \eta$.

${ }^{17}$ Por. Diogenes Apolloniates, F 51 A 1, w: FVS, vol. 1, s. 416, 38-39. Używał również terminu $\sigma \tau \rho о \gamma \gamma \tilde{\lambda} \lambda \eta$

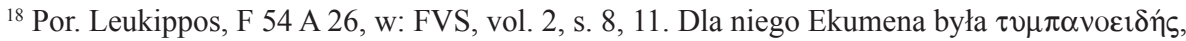
czyli miała kształt kotła lub bębna.

${ }^{19}$ Por. P. Fabre, Les Grecs et la connaissance de l'Occident, Lille 1981, 58: „Tout se passe comme si les Grecs d'une manière plus ou moins consciente avaient d'abord considéré l'oekumène comme divisée en deux zones principales, l'une englobant le Nord et l'Ouest, l'autre le Sud et l'Est'.

${ }^{20}$ Por. Herodotus, Historia IV 36; Aristoteles, Meteorologica II 5, 362 b 10.

${ }^{21}$ Por. Democritus, F 55 B 15(393), w: FVS, vol 2, s. 65, 33-35 (= Eudoxus Cnidaeus, F 276 a (80), w: FEK, s. 97, 31-33 = Dikaiarchos, F 109, w: Wehrli, s. 35, 30-32= Eratosthenes, F II C, 1,

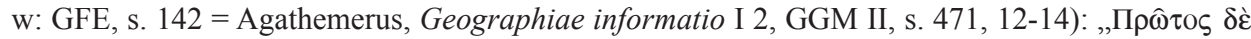

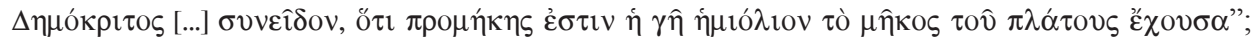
zob. Democritus, F 55 A 94(367), w: FVS, vol. 2, s. 33, 28.

${ }^{22}$ Por. Eudoxus Cnidaeus, F 276 a (80), w: FEK, s. 97, 34 (= Eratosthenes, F II C, 1, w: GFE, s. 142 = Agathemerus, Geographiae informatio I 2, GGM II, s. 471, 15-17); zob. Geminus, Elementa astronomiae 15(13), 4, PG 19, 833C; tamże 16(13), 3, PG 19, 836A; tamże 16(13), 5, PG 19, 836B. 
kartografii pod nazwą „,parallelogramu Efora”23, miał przypisać obrzeża ziemi konkretnym ludom. W ten sposób dłuższe północne i południowe kresy świata przypadły odpowiednio Scytom i Etiopom, krótsze natomiast, czyli zachodnie i wschodnie, Celtom i Indom (por. rys. 1B) ${ }^{24}$. W konsekwencji nakreślił on obraz peryferii, sugerując jednocześnie istnienie centrum, którego nazwy można się łatwo domyślić ${ }^{25}$. Z drugiej zaś strony schematyzacja Ekumeny, zawarta $\mathrm{w}$ dziele Efora, miała niezaprzeczalne walory mnemotechniczne ${ }^{26}$. Z kolei Arystoteles (384-322 prz. Chr.) określił proporcje długości do szerokości Ekumeny jako 5:327. Natomiast Dikajarch z Messeny (375/350-285 prz. Chr.) przejął cytowane wyżej proporcje Demokryta ${ }^{28}$. Eratostenes (276-194 prz. Chr.) zaś określił owe proporcje, podobnie jak Eudoksos z Knidos, na 2:129. Parallelogram jako schemat Ekumeny przejął również adwersarz Eratostenesa Strabon. Z obrazem Ekumeny w formie równoległoboku łączy się pojęcie tzw. „równika jońskiego”, który zdaniem Johna L. Myres’a (1869-1954) miał być swoistą osią symetrii, dzielącą horyzontalnie Ekumenę wzdłuż basenu Morza Śródziemnego na część północną i południową. Schemat ten, zdaniem cyto-

${ }^{23}$ Por. J. Lelewel, Historia geografii i odkryć, w: tenże, Pisma pomniejsze geograficzno-historyczne, Warszawa 1814, 19; W.A. Heidel, The frame of the ancient Greek maps, New York 1937 [repr.: New York 1976], s. 17, 47 i 50. „Parallelogram Efora” znajduje się również w: Cosmas Indicopleustes, Topographia Christiana II 79, PG 88, 116C; FHG I F 38, s. 244 [col. A]; FGrHist, II/A, s. 51, 26-36; SCh 141, s. 397. Natomiast średniowieczne szkice „parallelogramu Efora” znajdują się w trzech kodeksach (Vaticanus Graecus 699; Laurentianus Plut. IX. 28; Sinaïticus Graecus 1186), zawierających tekst dzieła Kosmasa Indikopleustesa (VI w.) Topographia Christiana, por. SCh 141, 396-397, przyp. 80.

${ }^{24}$ Por. Ephorus Cumaeus, 70 F 30a, w: FGrHist, II/A, s. 50, 31-51, 3 (=tenże, FHG I F 38, s. 244 [col. A] = Anhang (Aethiopien), 673 F 18a, w: FGrHist, III/C ${ }^{1}$, s. 292, 1-5 = Strabo, Geographica I 2, 28, C. 34); Ephorus Cumaeus, 70 F 30b, w: FGrHist, II/A, s. 51, 8-12 (= tenże, FHG I F 38, s. 243 [col. B] = Cosmas Indicopleustes, Topographia Christiana II 79, 1-5, SCh 141, $395=$ PG 88, 116B); Ephorus Cumaeus, 70 F 30c, w: FGrHist, II/A, s. 52, 1-9 (= tenże, FHG I F 43, s. 245 [col. A] = Pseudo-Scymnus, Orbis Descriptio 170-182, GGM I, s. 201-202).

${ }^{25}$ Por. J.F. Staszak, La géographie d'avant la géographie: le climat chez Aristote et Hippocrate. Préface de P. Claval, Paris 1995, 186: „Il s'agit d'une carte-image qui distribue les peuples, les ventes et les points solsticiaux autour de ce centre du monde que constitue la Grèce".

${ }^{26}$ Por. Ch. Jacob, Géographie et ethnographie en Grèce, Paris 1991, 53: „Il s'agit davantage d'un tracé mnémotechnique, offrant une répartition spatiale très générale, des repérages essentiels, et permettant une localisation approximative des peuples des confins de la terre. La carte se réduit ici à une épure intellectuelle, à un cadre".

${ }^{27}$ Por. Aristoteles, Meteorologica II 5, 362 b 23.

${ }^{28}$ Por. Dikaiarchos, F 109, w: Wehrli, s. 35, 32 (= Democritus, F 55 B 15(393), w: FVS, vol. 2, s. 65, 35 = Eudoxus Cnidaeus, F 276 a (80), w: FEK, s. 97, 33 = Eratosthenes, F II C, 1, w: GFE, s. 142 = Agathemerus, Geographiae informatio I 2, GGM II, s. 471, 12-15).

${ }^{29}$ Por. Eratosthenes, F II C, 1, w: GFE, s. 142 (=Eudoxus Cnidaeus, F 276 a (80), w: FEK, s. 97 , 34-35 = Strabo, Geographica I 4, 2, C. 63 = Agathemerus, Geographiae informatio I 2, GGM II, s. 471, 16-17); Eratosthenes, F II C, 18, w: GFE, s. 156 (= Strabo, Geographica I 4, 5, C. 64). 
wanego badacza, znajdował się już na tzw. mapie Anaksymandra ${ }^{30}$. Ponad dwa wieki później, cytowany wyżej Dikajarch, użył tego schematu jońskiego w swej teorii osi symetrii Ekumeny. W ten sposób „równik joński” miał przejść do historii geografii pod nazwą „diafragmy Dikajarcha" "31, czyli swoistej przepony Ekumeny. Hipoteza istnienia „równika jońskiego” jest dziś dość powszechnie akceptowana ${ }^{32}$.

Trzecim ze wspomnianych wyżej schematów jest półkolisty obraz Ekumeny Kratesa z Mallos. Geneza tego schematu geograficznego sięga rozważań Greków nad kształtem ziemi jako takiej. Chodzi rzecz jasna o kwestię kulistości naszej planety, z którą łączy się standardowo dwa imiona: Pitagorasa (ok. 580-510 prz. Chr.) i Parmenidesa (ok. 540-470 prz. Chr.). Zatem przynajmniej od VI wieku prz. Chr. określano ziemię przymiotnikiem $\sigma \varphi \alpha \iota \rho o \varepsilon ı \delta \eta ் ~ \varsigma^{33}$. Ich koncepcję przejęły najpoważniejsze autorytety naukowe starożytności, jak Platon (428/427-348/347 prz. Chr.), Eudoksos z Knidos, Autolikos z Pitane (IV/III w. prz. Chr.), Euklides (ok. 325-265 prz. Chr.), Arystoteles i Eratostenes. Zwolennikiem tej tezy był również Posejdoniusz z Apamei, Geminus (I w. prz. Chr.), Strabon i Ptolemeusz (ok. 80-165 po Chr.) ) $^{34}$ Krates z Mallos (ok.

${ }^{30}$ Por. J.L. Myres, An attempt to reconstruct the maps used by Herodot, „The Geographical Journal" 8 (1896) z. 6, 605-631; tenże, Herodotus: Father of History, Oxford 1953, 34-43.

${ }^{31}$ Por. Dicaearchus Messenius, w: FHG II F 55, s. 251 [col. B] = Agathemerus, Geographiae

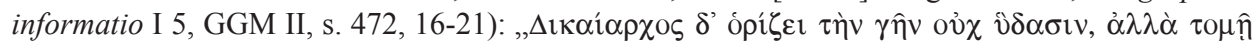

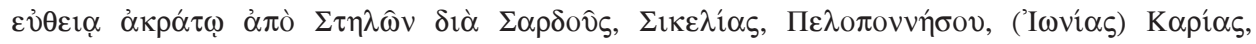

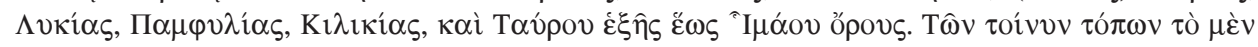

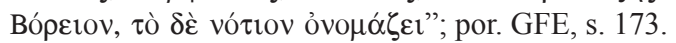

${ }^{32}$ Por. Heidel, The frame of the ancient Greek maps, s. 53-55; Ch. van Paassen, The classical tradition of geography, Groningen - Djakarta 1957, 39; Wolska-Conus, Geographie, szp. 158; G. Mangani, 'La macchina dei climi': enciclopedismo, geografia, economia scritturale, „Quaderni Urbinati de Cultura Classica" N.S. 14 (1983) 132, przyp. 1; W. Sieberer, Das Bild Europas in den Historien: Studien zu Herodots Geographie und Ethnographie Europas und seiner Schilderung der persischen Feldzüge, Innsbruck 1995, 18-19.

${ }^{33}$ Por. Parmenides, F 18 A 1, w: FVS, vol. 1, s. 138, 10-11 ; zob. tenże, F 18 A 44, w: FVS, vol. 1, s. 145, 16-18; zob. G. Pápay, Zur Frühgeschichte der Erdgloben, w: Térkép - Tudomány. Tanulmányok Klinghammer István professzor 65. születésnapia tiszteletére, szerkesztette (= Map Science. Papers in Honour of the $65^{\text {th }}$ Birthday of Prof. István Klinghammer, ed. L. Zentai), Budapest 2006, 332-333. Numeracja stron pochodzi z internetowej wersji tego artykułu dostępnego w całości na stronie: http://lazarus.elte.hu/un/digkonyv/sc/sc13/41gyula_papay.pdf [sprawdzono: 1.05.2011].

${ }^{34}$ Jeśli chodzi o bibliografię na temat idei kulistości ziemi zarówno w starożytności, jak i w średniowieczu, por. Kochanek, Die Vorstellung vom Norden und der Eurozentrismus, s. 220-221, przyp. 208. W literaturze polskiej por. też B. Gustawicz, Przyczynek do historyi globusu ziemskiego i niebieskiego od najdawniejszych czasów do końca wieku XV, Kraków 1902, 5-6; Bujak, Studia geograficzno-historyczne, s. 80, przyp. 2; J. Staszewski, Początki idei kulistości ziemi, „Przegląd Geograficzny" 33 (1961) 187-198; Strzelczyk, Gerwazy z Tilbury, s. 138-139; tenże, Uwagi o kartografii średniowiecznej, w: Problemy nauk pomocniczych historii, III, s. 101-102, 105-106 (= tenże, Średniowieczny obraz świata, s. 51-52. 55-56); tenże, Iroszkocki biskup Salzburga, problem antypodów i „Kosmografia” Aethicusa z Istrii, „Przegląd Historyczny” 74 (1983) 221-236; tenże, Drogi 
214-150 prz. Chr.), stoik i komentator Homera, skonstruował model globu$\mathrm{sa}^{35}$. Istotą modelu Kratesa był symetryczny podział ziemi na cztery części za pomocą dwóch, krzyżujących się pod kątem prostym tzw. „pasów oceanicznych"36. Jeden z nich dzielił ziemię na półkulę północną i południową, drugi zaś na półkulę wschodnią i zachodnią. W konsekwencji glob ziemski został podzielony na cztery równe, półkoliste Ekumeny. Jedną z nich zamieszkują ludzie, trzy pozostałe odpowiednio: Periojkowie, Antypodzi i Antiojkowie (por. rys. $1 C)^{37}$. Schemat globusa był zatem oparty na idei prostej, a co za tym idzie,

i bezdroża wiedzy o świecie, s. 8 (= tenże, Średniowieczny obraz świata, s. 68); tenże, „Contra naturam”? Czwarty kontynent i problem antypodów w starożytności i średniowieczu, „Czas Kultury” 18 (2002) nr 2(107), 10-24 (= tenże, „Klucz do poznania nieba”, s. 12-40); M.J. Karp, Znajomość kulistości ziemi w Kronice Kadtubka. Próba interpretacji toposu o pitce wystanej Aleksandrowi przez Dariusza, „Kwartalnik Historii Nauki i Techniki” 28 (1982) 139-146; D.J. Boorstin, Odkrywcy. Dzieje ludzkich odkryć i wynalazków, tłum. M. Stopa, Warszawa 1998, 89-96.

${ }^{35}$ Por. Strabo, Geographica II 5, 10, C. 116; tamże I 1, 7, C. 4-5; I 2, 24, C. 30; I 2, 31, C. 38 ; I 4, 6, C. 64; II 3, 7, C. 103; II 5, 18, C. 118; III 4, 4, C. 157; XIII 1, 55, C. 609; XIV 5, 16, C. 676. Wspomina o nim także Geminus, Elementa Astronomiae 16(13), 21-22, PG 19, 840B-C; 16(13), 1, PG 19, 833D; 16(13), 27, PG 19, 841A.

${ }^{36} \mathrm{Na}$ temat ,pasów oceanicznych” globusa Kratesa pisał Cicero (106-43 prz. Chr.), Makrobiusz (1 poł. V wieku po Chr.) i Martianus Capella (2 poł. V wieku po Chr.), por. Cicero, Academica II 39 , 123; tenże, Respublica VI 19, 20; VI 20, 21; tenże, Tusculanae disputationes I 28[68]; Macrobius, Commentarius in Somnium Scipionis II 5, 28-6, 2; II 9, 1-7; tamże II 5, 6; II 8, 1-2; Martianus Capella, De nuptiis Philologiae et Mercurii VI 590 i 603-606. Do teorii ,pasów oceanicznych” odwoływali się również inni autorzy starożytni, por. Lucretius, De natura rerum V 203-205; Vergilius, Aeneis VII 225-227; tenże, Georgica I 237-239; Pseudo-Tibullus, Panegyricus Messallae IV 1 (III 7), 150; Hyginus, Astronomia I 9, 165-172; Seneca (Maior), Suasoriae I 1; Ovidius, Metamorphoses I 45-51; Manilius, Astronomica I 246 i 377-381; Pomponius Mela, De chorographia I 4; Seneca (Minor), Epistulae ad Lucillum 88, 7; tenże, Naturales quaestiones V 17, 2-3, 362-365; Plinius, Naturalis historia II 170; Achilles, Isagoga 30 (= Commentariorum in Aratum reliquiae, ed. E. Maass, Berlin 1958², 65, 15-66, 25 = Achilles Tatius, Isagoge ad Arati Phaenomena, PG 19, 981C-D i 984A-C); Anonymus, Commentarius in Aratum 6 (= Commentariorum in Aratum reliquiae, s. 97 7-23 = PG 19, 1001B-1002A); Ampelius, Liber memorabilis 6 1; Apuleius, Metamorphoses I 8(38); Eumenius, Pro instaurandis scholis 9(4), 20, 2; Anonymus, Panegyricus Constantino Augusto dictus 5(8), 4, 2; Cleomedes, Caelestia (lub De motu circulari corporum caelestium) I 1, 209-234; Anonymus, Epitoma disciplinarum (Fragmentum Censorini), F IV 1; Rutilius Namatianus, De reditu suo sive Iter Gallicum I 643; Nonnos Panopolitanus, Dionysiaca II 247-248; Eustathius, Commentarii ad Odysseam X $86(1649,33)$.

${ }^{37}$ Kwestia źródeł, bibliografii oraz problem współczesnych rekonstrukcji globusa Kratesa zostały przedstawione w: Kochanek, Die Vorstellung vom Norden und der Eurozentrismus, s. 390393; tenże, Rekonstrukcje globusa Kratesa z Mallos w dwóch polskich podręcznikach historii geografii, „Acta Mediaevalia” 20 (2007) 139-152; tenże, Współczesne rekonstrukcje globusa Kratesa z Mallos, w: Archiva temporum testes. Źródła historyczne jako podstawa pracy badacza dziejów. Księa pamiątkowa ofiarowana Profesorowi Stanisławowi Olczakowi, red. G. Bujak T. Nowicki - P. Siwicki, Lublin 2008, 247-260; por. J. Strzelczyk, Na poludnie od równika (legenda o Antypodach), „Mówią Wieki” 10 (1967) nr 8(116), s. 1 i 3 (= tenże, Szkice średniowieczne, Poznań 1987, 82-84); tenże, „Contra naturam”?, s. 13 (= tenże, „Klucz do poznania nieba”, s. 18); 
łatwej do zapamiętania geometryzacji przestrzeni. Pojęcie $\dot{\eta} \mu \iota \kappa \hat{\kappa} \lambda \iota$ ıov, czyli półkole, jako termin oddający schemat Ekumeny, nie zrobiło jednak wielkiej kariery ani w starożytności, ani też w średniowieczu. Zupełnie inne były losy epitetu $\sigma \varphi \alpha \imath \rho o \varepsilon \imath \delta \eta ́ s$, który wszedł na stałe do kanonu podstawowych schematów geometrycznych.

Czwarty, przypisywany Hipparchowi, schemat to Ekumena mająca formę trapezu - $\tau \rho \alpha \pi \varepsilon \zeta o \varepsilon ı \delta$ Ł. O „trapezokształtnej” ziemi pisał już jednak znacznie wcześniej Anaksymenes (ok. 585-525 prz. Chr.) ${ }^{38}$. Działo się to jeszcze zanim Demokryt stworzył swój schemat podługowatej ( $\pi \rho \mu \eta \dot{\kappa \eta \varsigma) ~ E k u m e n y . ~}$ Być może w stworzeniu tego schematu pomógł Demokrytowi właśnie trapez Anaksymenesa. Trapez to przecież czworobok ( $\tau \varepsilon \tau \rho \alpha ́ \alpha \lambda \lambda \varepsilon v \rho o v)$ i to równoległoboczny ( $\pi \alpha \rho \alpha \lambda \lambda \eta \lambda o_{\gamma} \rho \alpha \mu \nu$ ), a Demokryt, jak to dopiero co wykazano, rozumiał grosso modo podługowatość Ekumeny jako jej prostokątność. Jednak imię Hipparcha kojarzyło się zapewne w czasach Agatemera lepiej z wielką geometrią minionych wieków, niż imię Anaksymenesa, stąd też on właśnie został uznany za „ojca chrzestnego" tego schematu. Warto przy tym zauważyć, że kształt trapezu miała chlamida (por. rys. 1D), do której przynajmniej od czasów Eratostenesa porównywano kształt Ekumeny $(\chi \lambda \alpha \mu \nu \delta o \varepsilon 1 \delta \eta ́ \varsigma)^{39}$. Kształt Ekumeny-chlamidy korespondował z kształtem planu Aleksandrii ${ }^{40}$,

A. Piskozub, Rozwój horyzontu geograficznego, Gdańsk 1993, 98-100; tenże, Morze w dziejach cywilizacji, Toruń 1999, 99-100; tenże, Historia poznania Wszechoceanu, Toruń 2004, 94-96; M. Sirko, Zarys historii kartografii, Lublin 1999, 21 i 284.

${ }^{38}$ Por. Anaximenes, F 3 A 20, w: FVS, vol. 1, s. 25, 27.

${ }^{39}$ Por. Eratosthenes, F II B, 27, w: GFE, s. 116 (= Strabo, Geographica II 5, 6, C. 113); zob. też Strabo, Geographica II 5, 7, C. 113; II 5, 14, C. 118; II 5, 14, C. 119; II 5, 18, C. 122; XI 11, 7, C. 519; Plinius, Naturalis historia V 62: ,ad effigiem Macedonicae chlamydis”; Macrobius, Commentaria ad Somnium Scipionis II 9, 8; Chrestomathia Straboniana II 16, GGM II, s. 537; tamże, II 24, GGM II, s. 538. Kwestię tę gruntownie omówił H. Berger (GFE, s. 219-221). Tenże autor pisał (GFE, s. 220) też o tezie Joachima Lelewela (1786-1861): „Lelewel [J. Lelewel, Kleinere Schriften geographisch-historischen Inhalts, aus dem Polnischen übersetzt von K. Neu, Leipzig 1836, 30] vergleicht die Chlamysgestalt mit zwei der Breite nach aneinandergelegten Bischofsmützen und nähert sich somit der Beschreibung des Dionysius Periegetes und der $\sigma \varphi \varepsilon v \delta$ óvๆ des Posidonius". W polskiej literaturze przedmiotu schemat ten przywołują m.in.: Gustawicz, Zarys historii sposobów kreślenia kart geograficznych, s. 7; J. Haliczer [= J. Staszewski], Rewizja pogladów na starożytna puściznę geograficzna, „Przegląd Klasyczny” 5 (1939) nr 3-5, s. 247; J. Staszewski, Środowisko geograficzne w nauce antycznej, s. 37; Strzelczyk, Uwagi o kartografii średniowiecznej, s. 108 (= tenże, Średniowieczny obraz świata, s. 57).

${ }^{40}$ Por. Diodor Siculus, Bibliotheca XVII 52, 3; Strabo, Geographica XVII 1, 8, C. 793; Plinius, Naturalis historia V 62; Plutarchus, Vita Alexandri 26, 5; Eustathius, Commentarii 157, GGM II, s. 245, 30-31; Scholia ad Dionysium 1165, GGM II, s. 457(col. B), 44-45; zob. też GFE, s. 220221: „[Konrad] Mannert deutet (Einleitung in die Geographie der Alten und Darstellung ihrer vorzüglichen Systeme, Leipzig 1829, 89 i 116), dass die Chlamysgestalt der Weltstadt Alexandria die Brücke zu jener Vergleichung gewesen sei und geht bis zu der Vermuthung, Aristoteles könnte schon eine ähnliche Gestalt der Oekumene gelehrt und Alexander den Grundriss der zu erbaunden Stadt darnach eingerichtet haben"; zob. również: tenże, Geschichte der wissenschaftlichen 
niedoszłej stolicy królestwa Aleksandra Macedońskiego (356-323 prz. Chr.). Powstał w ten sposób pewien geometryczny model, gdzie schemat stolicy odpowiadał schematowi przyszłego „ekumenicznego" imperium. Aż się prosi, aby podobny schemat przybrał pałac tego władcy lub jego monumentalny grobowiec. W ten sposób byłby to kolejny przykład swoistej trójstopniowej schematyzacji koncentrycznej, uchwytnej już u Herodota (ok. 484-425 prz. Chr.). Ten ostatni bowiem opisał terytorium scytyjskie tak, że jego schemat jest określany powszechnie mianem Scythia quadrata ${ }^{41}$. Formę kwadratu ma jednak u „Ojca historii” nie tylko sam obszar Scytii, lecz również grób króla Scytów oraz świątynia Aresa, naczelnego, zdaniem Herodota, bóstwa tych nomadów ${ }^{42}$. Podobny schemat sugerował Herodot również w przypadku Egiptu. Opisując kraj nad Nilem wspomniał on bowiem o podziale ziemi dokonanym tam przez faraona Sezostrisa ${ }^{43}$; w jego efekcie każdy Egipcjanin miał otrzymać czworoboczną działkę ${ }^{44}$. Zarówno w przypadku opisu kwadratowego kształtu Scytii, jak i przy opisach scytyjskiej świątyni Aresa, grobu króla Scytów oraz działek Egipcjan, historyk z Halikarnasu użył terminu $\tau \varepsilon \tau \rho \alpha ́ \gamma \omega \omega \gamma o \varsigma$. Wynika stąd, że wszystkie te elementy miały w jego odczuciu kształt kwadratu. Należy również pamiętać o tym, że piramidy, czyli znane Herodotowi z autopsji grobowce faraonów, miały także kwadratową podstawę. Podobnie można (stosując pewne uproszczenie) postrzegać egipskie kompleksy świątynne. Idąc dalej, można sądzić, że Herodot traktował Egipt jako taki także jako kwadrat, czyli swoiście rozumianą sumę wspomnianych wyżej nadziałów ziemi. W konsekwencji Scythia quadrata na północy koresponduje

Erdkunde der Griechen, Bd. 3: Die Geographie der Erdkugel, Leipzig 1891, 78; G. Botti, Plan de la ville d'Alexandrie à l'époque ptolmaïque: monuments et localités de l'ancienne Alexandrie d'après les écrivains et les fouilles, Alexandrie 1898 [non vidi]; F.B. Tarbell, The form of the Chlamys, CPh 1 (1906) 283-289; C. Préaux, Alexandrie et la chlamyde, „Chronique d'Égypte” 43 (1968) 176-187; P.M. Fraser, Ptolemaic Alexandria, vol. 2: Notes, Oxford 1972, 26, przyp. 4; J. Siat, Alexandrie: à la recherche d'une ville perdue, „Monde de la Bible” 1979, nr 8, 10-18; A.F. Steward, Faces of power: Alexander's image and hellenistic politics, Berkeley 1993, 238-239 i przyp. 29. Plany miasta pochodzące z różnych epok są dostępne na stronie internetowej Maps of Alexandria: www.alexanderstomb.com/main/imageslibrary/maps/index.htm [sprawdzono: 1.05.2011].

${ }^{41}$ Por. Herodotus, Historia IV 100-101. Powyższy akapit poświęcony Herodotowi jest zmodyfikowanym streszczeniem wywodu zamieszczonego w: Kochanek, Die Vorstellung vom Norden und der Eurozentrismus, s. 83-84. Podobne, choć również odpowiednio do kontekstu przerobione streszczenie znajduje się w: P. Kochanek, Periodyzacja dziejów ludzkości Epifaniusza z Salaminy, w: Byzantina Europaea. Księga jubileuszowa ofiarowana Profesorowi Waldemarowi Ceranowi, red. M. Kokoszko - M.J. Leszka, Łódź 2007, 233-234.

${ }^{42}$ Por. Herodotus, Historia IV 62, 71 i 101; zob. F. Hartog, Le boeuf „autocuiseur” et les boissons d'Arès, w: La cuisine du sacrifice en pays grec, éd. M. Detienne - J.P. Vernant, Paris 1979, 262.

${ }^{43}$ Zwykle przyjmuje się, że chodzi o Sezostrisa III, władcę XII dynastii, który panował w latach 1878-1839 prz. Chr. Wiadomo jednak, że Herodot utożsamiał tego faraona z Ramzesem II (XIX dynastia), władającym w Egipcie w latach 1279-1213 prz. Chr.

${ }^{44}$ Por. Herodotus, Historia II 109. 
z Aegyptus quadrata na południu ${ }^{45}$. Wracając jednak do „chlamidokształtnej” Ekumeny, trzeba podkreślić, że schemat ten był łączony z dwoma innymi: otóż

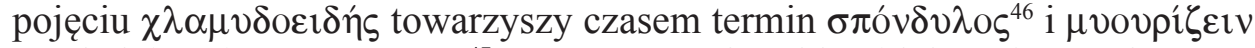
względnie $\mu$ v́ovpov $\sigma \chi \hat{\eta} \mu \alpha^{47}$. W ten sposób „chlamidokształtna” Ekumena

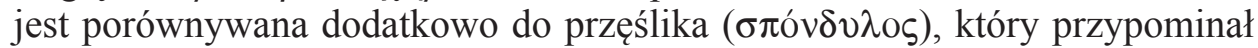
ścięty stożek (a z profilu trapez), a jej wschodnie i zachodnie krańce do spiczastości mysiego ogona.

Piąta opinia przytoczona przez Agatemera głosiła, że Ekumena jest oủpoeı́ńs, czyli że przypomina swych kształtem ogon lub kitę. Jest to prawdopodobnie wariant dopiero co przedstawionego poglądu, iż wschodnie i zachodnie krańce Ekumeny przypominają swą spiczastością mysi ogon.

Wreszcie szósta teza na temat schematu zamieszkałej ziemi, przypisywana Posydoniuszowi, głosiła, że Ekumena ma kształt (łoża) procy $(\sigma \varphi \varepsilon v \delta o ́ v \eta)^{48}$. Słowo $\sigma \varphi \varepsilon v \delta o ́ v \eta$ może też oznaczać zagłębienie w pierścionku, w którym umieszczało się kamień (pala annuli) ${ }^{49}$ (por. rys. $1 \mathrm{~F}$ ); pojęcie to nie jest więc jednoznaczne. Jednakże zarówno łoże procy, jak i łoże pierścienia, zdają się

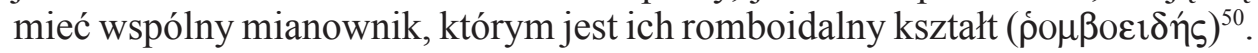
Idąc dalej, można stwierdzić, że kształt ten, to w gruncie rzeczy dwa przylegające do siebie podstawami trójkąty równoboczne lub równoramienne, z których jeden reprezentuje Azję, drugi natomiast daje po symetrycznym podziale wzdłuż linii wyznaczonej przez wysokość tego trójkąta dwa trójkąty prosto-

${ }^{45}$ Por. Kochanek, Die Vorstellung vom Norden und der Eurozentrismus, s. 79-85; tenże, Periodyzacja dziejów ludzkości Epifaniusza z Salaminy, s. 233-237; tenże, Pesymizm schyłku Republiki Rzymskiej. Idea starzenie się świata i następstwa imperiów, w: Veritatem in caritate. Księga Jubileuszowa z okazji 70. urodzin Księdza Biskupa Profesora Jana Śrutwy, red. W. Depo M. Leszczyński - T. Guz - P. Marzec, Lublin 2011, 581-582.

${ }^{46}$ Por. Eratosthenes, F II B, 27, w: GFE, s. 115 (= Strabo, Geographica II 5, 6, C. 113); zob. też Strabo, Geographica II 5, 13, C. 118; Chrestomathia Straboniana II 16, GGM II, s. 537.

${ }^{47}$ Por. Strabo, Geographica II 5, 6, C. 113; II 5, 14, C. 119.

${ }^{48}$ Posidonius Apamensis, F 68a, w: Theiler, t. 1, s. 71-72 (= Agathemerus, Geographiae informatio I 2, GGM II, s. 471, 18-21); Posidonius Apamensis, F 68b, w: Theiler, t. 1, s. 72 (= Eustathius, Commentarii ad Homeri Iliadem VII 446); Posidonius Apamensis, F 68c, w: Theiler, t. 1, s. 72 (= ustathius, Commentarii [1], GGM II, s. 217, 32-34. 38-41); por. Democritus, F 55 A 94(367), w: FVS, vol. 2, s. 33, 28; Dionysius Periegetes, Orbis descriptio 3-7, GGM II, s. 104-105; Eustathius, Commentarii 39, GGM II, s. 225, 28-31; 620. 623, GGM II, s. 334, 4-6. 24-31; 718, GGM II, s. 344, 18-19; Anonymus, Paraphrasis 18, GGM II, s. 409; Scholia ad Dionysium 1, GGM II, s. 430(col. A), 4-12; tamże, 3. 7, GGM II, s. 430 (col. B), 22, 24-35 i 36; Nicephorus Blemmides, Geographia synoptica 1-7, GGM II, s. 458(col. A), 7; zob. też GFE, s. 220; K. Abel, Poseidonios und Senecas Trostschrift an Marcia (Dial. 6,24,5ff), „Rheinisches Museum” 107 (1964) 244; G. Maurach, Africanus Maior und die Glaubwürdigkeit des „Somnium Scipionis”, „Hermes” 92 (1964) 311, przyp. 1.

${ }^{49}$ Por. Eustathius, Commentarii 7, GGM II, s. 218, 19-35.

${ }^{50}$ Zdaniem H. Berger'a (Geschichte der wissenschaftlichen Erdkunde der Griechen, Leipzig $1903^{2}$ [repr.: Berlin 1966], 432-433) pierwsze porównanie kształtu Ekumeny do rombu było dziełem Eratostenesa, por. Anonymus, Geographiae expositio compendiaria 13, 39, GGM II, s. 504, 11. 
kątne, które schematyzują Europę i Afrykę (= Libię) $)^{51}$. Owe dwa trójkąty równoramienne lub równoboczne, które przylegając do siebie podstawami two-

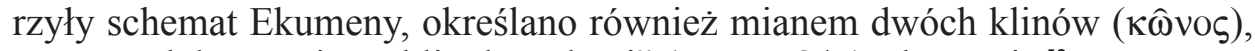

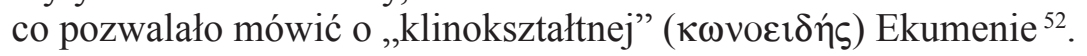

Poza makro-schematami przytoczonymi przez Agatemera, historia geografii grecko-rzymskiej zna również inne, warte przypomnienia schematy makroekumeniczne. Porównanie Ekumeny do trójkątnego instrumentu muzycznego

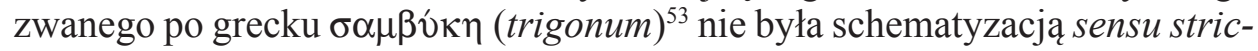
to, lecz miała służyć wyjaśnieniu różnic w brzmieniu głosu poszczególnych ludów Ekumeny.

Również porównania zamieszkałej ziemi do wyspy $(v \widehat{\eta} \sigma o \varsigma)^{54}$, oblanej oceanem, nie można traktować jako schematyzacji w ścisłym tego słowa znaczeniu. Jest to jednak pośrednio pewien schematyczny obraz, przemawiający do wyobraźni słuchacza lub czytelnika. Obraz ten może wywoływać wiele refleksji natury egzystencjalnej, stąd należy go traktować jako filozoficznopoetycką wizję Ekumeny.

Generalnie zatem starożytność grecko-rzymska posiadała dwa ogólne schematy: 1. kolisto-kulisty schemat Ekumeny i ziemi jako takiej; 2. czworoboczny schemat Ekumeny. Każdy z nich opiera się na geometryzacji przestrzeni. Implikuje przy tym ideę proporcji, symetrii oraz ideę centrum. Prostota i jasność tych schematów sprawia, że wszystkie one były łatwe do zapamię-

${ }^{51}$ Jeśli chodzi o trójkąt prostokątny jako schemat Afryki-Libii, por. Eratosthenes, F III B, 55,

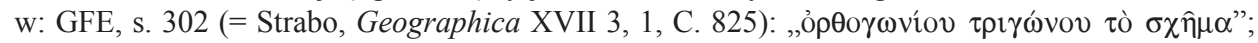
zob. Chrestomathia Straboniana XVII 50, GGM II, s. 635; Eustathius, Commentarii 175, GGM II, s. 246, 45-247, 1; por. też Strabo, Geographica XVII 3, 2, C. 826: „,

${ }^{52}$ Takim schematem została scharakteryzowana Azja, por. Dionysius Periegetes, Orbis descriptio 620-621, GGM II, s. 143; Eustathius, Commentarii [1], GGM II, s. 217, 34-38. 41-44: jest tu mowa o wszystkich trzech kontynentach; tamże 620, GGM II, s. 333, 35-39 i s. 334, 7-8; Anonymus, Paraphrasis 620-626, GGM II, s. 418; Scholia ad Dionysium 7, GGM II, s. 431(col. A), 1-2: tu obok Azji jest także mowa o Libii; tamże 620, GGM II, s. 452(col. B), 17-20. Tak też schematycznie zostały przedstawione Europa i Afryka/Libia, zob. Dionysius Periegetes, Orbis descriptio 277, GGM II, s. 116; 620-622, GGM II, s. 143; Eustathius, Commentarii 274, GGM II, s. 265, 25-28; 620, GGM II, s. 333, 35-41; Anonymus, Paraphrasis 254-269, GGM II, s. 413; 620-626, GGM II,

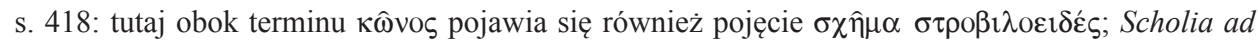
Dionysium 275, 277 i 281, GGM II, s. 442(col. B), 3-5, 6-8, 15; 620, GGM II, s. 452(col. B), 18; zob. też K. Brodersen, Antike Weltbilder im Widerspruch zwischen Theorie und Praxis, w: Weltbilder, hrsg. H. Gebhardt -H. Kiesel, Berlin - Heidelberg 2004, 121, przyp. 46.

${ }^{53}$ Por. Posidonius Apamensis, F 71, 5, w: Theiler, t. 1, s. 73 (= tenże, 87 F 121, w: FGrHist, II/A, s. $313,7-8=$ Vitruvius, De architectura VI 1, 5).

${ }^{54}$ Taki obraz daje już Homerowy opis tarczy Achilles, por. przyp. 12. Podobna sugestia znajduje się w opisie Atlantydy, por. Plato, Timaeus III 24E-25A; tenże, Critias III 108E. Jeszcze wyraźniej insularny charakter Ekumeny został przedstawiony w opisie ziemi z lotu ptaka, por. tenże, Phaedo LIX 110B; zob. też Eratosthenes, F II B, 27, w: GFE, s. 115. 116 (= Strabo, Geographica II 5, 6, C. 113); Posidonius Apamensis, F 2(5b), w: Theiler, t. 1, s. 16 (= Strabo, Geographica I 1, 8, C. 5); Strabo, Geographica II 5, 5, C. 112. 113. 
tania. Wiele schematów greckich, szczególnie tych najdawniejszych, cechuje jednoznaczny hellado- $\mathrm{i}$ hellenocentryzm.

W formie podsumowania tej części wywodów warto przedstawić graficznie dopiero co scharakteryzowane makro-schematy Ekumeny.

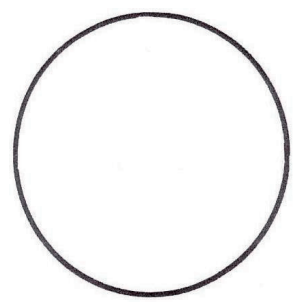

A. Okrąg

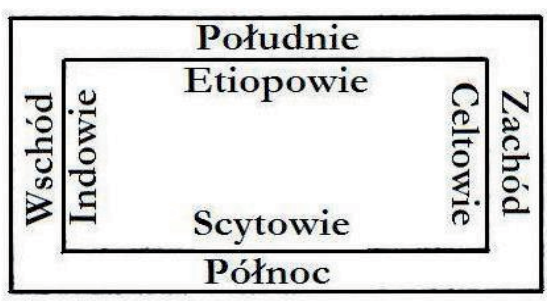

B. „Parallelogram Efora”

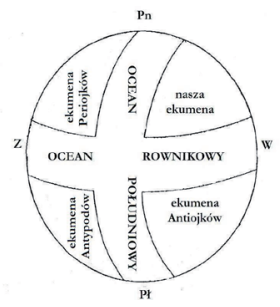

C. Globus

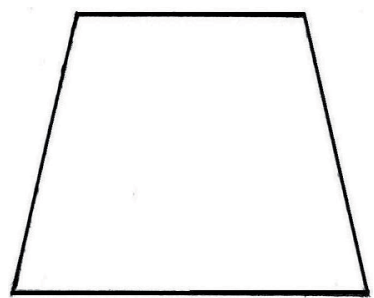

D. Trapez

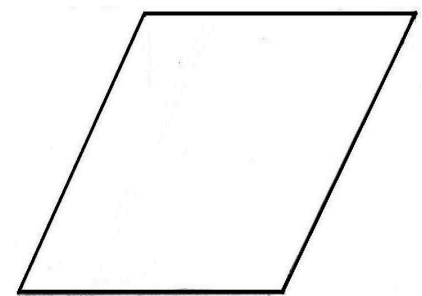

E. Romb

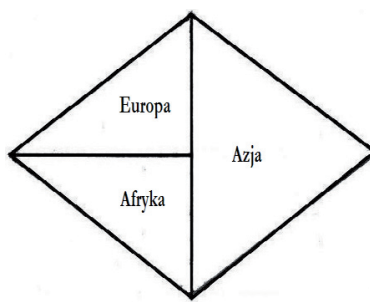

F. Sphendone

Rys. 1: Podstawowe greckie makro-schematy geograficzne ${ }^{55}$.

Istnieje też w literaturze greckiej specyficzny schemat znanego wówczas świata, przedstawiony w dziele De hebdomadibus ${ }^{56}$, wchodzącym w skład Corpus Hippocraticum, który może być traktowany jako reminiscencja antropologicznej koncepcji mikro- i makrokosmosu ${ }^{57}$. Zgodnie z tym schematem,

${ }^{55}$ Schemat B, czyli „parallelogram Efora”, jest inspirowany schematami zamieszczonymi w pracach J. Lelewela (Historia geografii i odkryć, s. 19) i W.A. Heidela (The frame of the ancient Greek maps, s. 17, rys. 2). Natomiast schemat globusa Kratesa z Mallos ma swój pierwowzór w rekonstrukcji zaproponowanej przez H. Bergera (Geschichte der wissenschaftlichen Erdkunde der Griechen, s. 216, rys. 3).

${ }^{56}$ Schematowi temu autor niniejszych rozważań poświęcił o wiele więcej miejsca w oddanym już do druku artykule: Etnomedycyna hippokratejska a geopolityczna myśl grecka w V wieku prz. Chr., który ukaże się w serii Studia nad Wiedza, t. 4: Kontrowersje dyskursywne - pomiędzy wiedza specjalistyczna a praktyka społeczna, wydawanej przez Instytut Socjologii KUL. Tutaj zamieszczono fragmenty tych rozważań istotne w kontekście niniejszych analiz, por. przyp. 69.

${ }^{57} \mathrm{~W}$ polskiej literaturze przedmiotu najgłębszą refleksję na ten temat zawarł w swych artykułach ks. prof. Marian Kurdziałek (1920-1997) - Koncepcja człowieka jako mikrokosmosu, w: O Bogu i człowieku, red. B. Bejze, t. 2, Warszawa 1969, 109-125; tenże, Der Mensch als Abbild des Kosmos, w: Der Begriff des Representatio im Mittelalter: Stellvertretung, Symbol, Zeichen, Bild, hrsg. A. Zimmermann, Berlin - New York 1971, 35-75 (= tenże, Średniowieczne doktryny o człowieku jako obrazie świata, RF 19 (1971) 5-39= tenże, Średniowiecze w poszukiwaniu równowagi między arystotelizmem a platonizmem: Studia i artykuły, Lublin 1996, 271-310); zob. też A. Bednarczyk, 
Ekumena dzieli się na siedem części: 1. głową jest Peloponez ${ }^{58}$, 2. szyja to Istm Koryncki, 3. Jonia to przepona, 4. Hellespont stanowi biodra, 5. Bosfor Tracki i Kimeryjski to stopy, 6. Egipt i Morze Egipskie oznacza brzuch, 7. natomiast Morze Czarne i Meotyda są traktowane jako podbrzusze i odbytni$\mathrm{ca}^{59}$. Schematowi temu poświęcono sporo uwagi ${ }^{60}$, jednak najgłębiej w jego istotę wniknął Wilhelm H. Roscher (1845-1923) ${ }^{61}$. On to w swych drobiazgo-

Motywy regulacyjne $w$ rozprawie ,De diaeta” z ,Corpus Hippocraticum”, „Kwartalnik Historii Nauki i Techniki” 37 (1992) nr 4, 71-72.

${ }^{58}$ Peloponez schematyzowano w starożytności również w inny sposób: 1) najbardziej znanym schematem tego półwyspu jest liść platanu, por. Strabo, Geographica II 1, 30, C. 83-84; VIII 2, 1, C. 335, por. też Isidorus Characenus, 781 F 12, w: FGrHist, III/C², s. 784, 7 (= tenże, Mansiones Parthicae 32, GGM I, s. 256 = Plinius, Naturalis historia IV 9); Pomponius Mela, De chorographia II 34; Dionysius Periegetes, Orbis descriptio 404, GGM II, s. 128; Agathemerus, Geographiae informatio V 24, GGM II, s. 484, 8-9; Solinus, Collectanea rerum memorabilium 7, 17; Avienus, Descriptio orbis terrae 563, GGM II, s. 182; Priscianus, Periegesis 401-402, GGM II, s. 193;

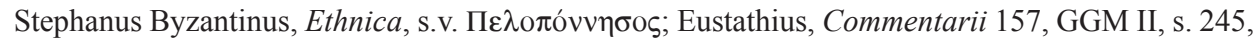
32-33; 403, GGM II, s. 291, 22.32; Anonymus, Paraphrasis 403-422, GGM II, s. 414-415; Scholia ad Dionysium 404, GGM II, s. 446(col. B), 15-23; Nicephorus Blemmides, Geographia synoptica 403-419, GGM II, s. 461(col. A-B), 44 ${ }^{\mathrm{A}} 3^{\mathrm{B}}$; zob. także Isidorus Hispalensis, Etymologiae XIV 6, 15, PL 82, 507A: „Arcadia vero sinus Achaiae est, ut platani folium inter Ionium et Aegeum mare exposita" (= Rabanus Maurus, De universo XII 4, PL 111, 349D). 2) Mniej znane jest porównanie Peloponezu do głowy wołu, por. Polybius, Historiae VII 12, 3 (akropol Messene, czyli góra Itome, i akropol Koryntu, czyli Akrokorynt, to dwa rogi Peloponezu); Strabo, Geographica VIII 4, 8, C. 361. 3) Określano go również mianem „Akropolu Hellady”, por. Strabo, Geographica VIII 1, 3, C. 334; Phlegon Trallianus, 257 F 1, w: FGrHist, II/B, s. 1161, 1 (= FHG III F 1, s. 603 [col. B]); Eustathius, Commentarii 403, GGM II, s. 291, 34-35.

${ }^{59}$ Pseudo-Hippocrates, De hebdomadibus 11 (Ambrosius latinus G 108): „Terra autem omnis septem partes habet: caput et faciem, P〈e〉lopon〈nes`um [Pylopontium Hs], magnarum animarum habitationem. Secundum I sth $>$ mus [Idymus Hs], medella, cervix. Tertia pars, inter viscera 〈media〉 [et] praecordia, I〈o`nia[e] [Iuniae Hs]. Quarta, crura Hell<e`spontus. Quinta, pedes, Bosporus transitus, Trachias et [Ho]c[h]imer<i>us. Sexta, venter, Aegyptus et pelagum Aegyptium. Septima, venter inferior et longa $\prec$ b o intestinum maius, 〈E〉uxinus Pontus et Palus Meot[h]is”.

${ }^{60}$ Por. W. Kubitschek, Karten, RE X 2, Stuttgart 1919, 2048, 15-27; M.L. West, The cosmology of 'Hippocrates' „,De hebdomadibus”, CQ 21 (1971) 365-388; G. Lachenaud, Connaissance du

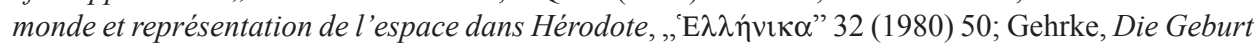
der Erdkunde aus dem Geist der Geometrie, s. 181-182, przyp. 99; F. Le Blay, Microcosm and macrocosm: the dual direction of analogy in Hippocratic thought and the meteorological tradition, w: Hippocrates in Context. Papers read at the XI International Hippocrates Colloquium (University of Newcastle, 27-31 August 2002), ed. Ph.J. van der Eijk, Leiden 2005, 251-269 [non vidi]. Na gruncie polskim, por. R. Ganszyniec, De Graecorum imagine mundi, „Eos” 35 (1934) 115-116; E. Schnayder, O mapie antycznej, „Meander” 10 (1955) 310; Kochanek, Die Vorstellung vom Norden und der Eurozentrismus, s. 163-164 i przyp. 2.

${ }^{61}$ Por. W.H. Roscher, Die Hebdomadenlehren der griechischen Philosophen und Ärzte: ein Beitrag zur Geschichte der griechischen Philosophie und Medizin, Leipzig 1906, 51. Praca ta jest również dostępna $\mathrm{w}$ internecie: www.slub-dresden.de/sammlungen/digitale-sammlungen/listenansicht [sprawdzono: 23.02.2011]; tenże, Über Alter, Ursprung und Bedeutung der hippokratischen Schrift von der Siebenzahl: ein Beitrag zur Geschichte der ältesten griechischen Philosophie und 
wych analizach powyższego obrazu świata zwrócił uwagę na kilka ważnych momentów: 1) na znaczenie siódemki zarówno w tytule samego traktatu, jak i w kontekście rzeczonej mapy (por. przyp. 61); 2) na zestawienie siedmiu części ciała ludzkiego z siedmioma regionami geograficznymi, które to zestawienie odsyła niejako automatycznie do koncepcji mikro- i makrokosmosu ${ }^{62}$; 3) na podkreślenie roli Peloponezu poprzez przyznanie mu roli głowy ${ }^{63}$; 4) oraz na szczególne miejsce Jonii: kraina ta została przedstawiona jako przepona ( $\varphi \rho \varepsilon ́ v \varepsilon \varsigma \varsigma$ lub $\delta ı \alpha ́ \alpha \rho \alpha \gamma \mu \alpha$ - por. przyp. 31, łac. praecordia), a ta część ciała była utożsamiana z siedliskiem duszy rozumnej. Co więcej, wśród siedmiu planet ,der Mond als Sitz der denkenden Weltseele entspricht sonach ganz deutlich dem Zwerchfell als dem Sitz des menschlichen Verstandes, auch insofern, als er und seine Sphäre ebenso die Grenze zwischen der oberen und unteren Welt bedeuten, wie das Zwerchfell (und der Nabel) die Mitte oder die Scheidewand zwischen dem Ober- und Unterkörper des Menschen bildet" 64 . $\mathrm{W}$ ten sposób siedem części ciała ludzkiego zostało powiązanych nie tylko z siedmioma regionami Ekumeny, lecz również z siedmioma ciałami niebieskimi. W konsekwencji powstała potrójny koniunkcja „siódemek”, z jednoczesnym wskazaniem na centrum, którym w przypadku ciała ludzkiego jest przepona - siedziba duszy rozumnej, w przypadku ciał niebieskich księżyc (w pełni) - siedziba duszy (wszech)świata, a w sferze geograficznej umbilicus mundi to Jonia. Zestawienie to sugeruje jednoznacznie, że Jonia została tutaj potraktowana jako swego rodzaju ,dusza rozumna” Ekumeny. W.H. Roscher starał się także odnaleźć mapę, która mogła ewentualnie być źródłem inspiracji, dla stworzenia tej konstrukcji. Domniemany model znalazł w pracy Heinricha K. Brugscha (1827-1894) ${ }^{65}$. Nie jest to jednak model kartograficzny, lecz kosmograficzny, ukazujący związek pomiędzy egipską boginią nieba - Nut, a bogiem ziemi o imieniu Geb. Najważniejsze w tej konfiguracji dwóch bóstw jest jednak „ekwilibrystyczne” wygięcie ciała boga ziemi, co pozwala na porównanie z przedstawioną wyżej antropomorficzną mapą. Można przy-

Prosaliteratur, Leipzig 1911, 10-13. Praca ta jest dostępna w internecie: www.slub-dresden.de/ sammlungen/digitale-sammlungen/listenansicht [sprawdzono: 23.02.2011]; tenże, Das Alter der

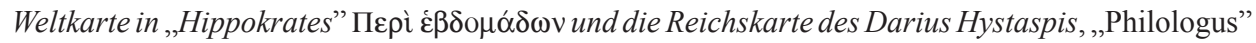
70 (1911) 529-531; tenże, Die neuentdeckte Schrift eines altmilesischen Naturphilosophen und ihre Beurteilung durch H. Diels in der Dt. Lit. Ztg., Berlin 1912 = „Sonderabdruck aus «Memnon»” 5 (1912) Heft 3-4, 23-25 i 41; tenże, Die hippokratische Schrift von der Siebenzahl und ihr Verhältnis zum Altpythagoreismus: ein Beitrag zur Geschichte der ältesten Philosophie und Geographie, Leipzig 1919, 1-4; zob. też Die hippokratische Schrift von der Siebenzahl in ihrer vierfachen Überlieferung, zum erstenmal hrsg. und erläutert von W.H. Roscher, Paderborn 1913 [repr.: New York 1967], 118.

${ }^{62}$ Por. Roscher, Über Alter, Ursprung und Bedeutung der hippokratischen Schrift, s. 16.

${ }^{63}$ Por. tamże, s. 28-33.

${ }^{64}$ Tamże, s. 16. Jeśli chodzi o cały wywód autora na ten temat, por. tamże, s. 13-28.

${ }^{65}$ Por. H.K. Brugsch, Religion und Mythologie der alten Ägypter nach der Denkmälern, Leipzig $1891^{2}, 211$. 
jąć, że taki rodzaj przedstawiania Geba, czyli jego nienaturalnie wygięte ciało, mogło być dla Greków potencjalnym źródłem inspiracji.

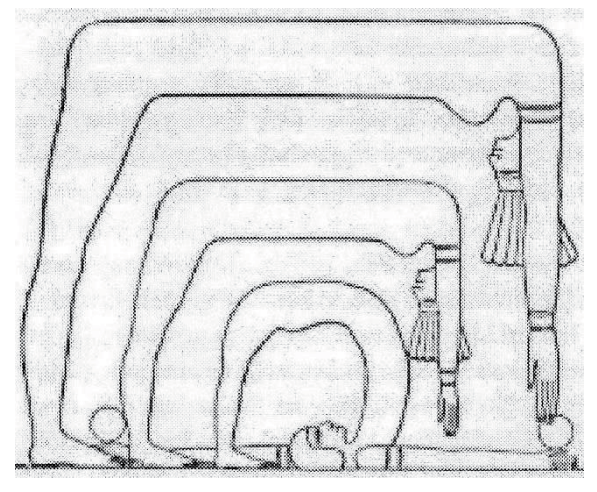

Rys. 2: Egipska bogini nieba Nut i bóg ziemi $\mathrm{Geb}^{66}$.

Z drugiej strony antropomorficzną mapę z De hebdomadibus cechuje wręcz skrajny hellado- i hellenocentryzm, który każe jego autorowi powierzyć Jonii funkcję omphalosa. Scytia i Egipt tymczasem zostały potraktowane z niezwykłą wręcz arogancją. W przypadku Egiptu można, być może, mówić o posuniętej do ostatecznych granic ironii, jaką Hellenowie przejawiali niejednokrotnie $\mathrm{w}$ stosunku do kultury egipskiej jako takiej ${ }^{67}$. Fakt ten można tłumaczyć z jednej strony greckim poczuciem wyższości w stosunku do północnych i południowych rubieży Ekumeny, z drugiej natomiast można całą tę koncepcję potraktować jako antropomorficzną, czy też anatomiczną karykaturę obrazu świata. Karykatura ta jest jednak wyraźnie zorientowana zgodnie z czterema stronami świata: zachód to Peloponez (Grecja), wschód to grecka Jonia (Azja Mniejsza), północ to Scytia, południe - Egipt. Punktem przecięcia tych dwóch osi świata jest niewzmiankowane w tekście Morze Egejskie.

Obok mapy antropomorficznej z De hebdomadibus, historia literatury greckiej zna jeszcze jeden podobny obraz świata, przekazany w hermetycznych

${ }^{66}$ Por. Roscher, Über Alter, Ursprung und Bedeutung der hippokratischen Schrift, s. 12, przyp. 15; zob. tenże, Die neuentdeckte Schrift eines altmilesischen Naturphilosophen, rys. 1.

${ }^{67}$ Warto przypomnieć, że Grecy nadali ironiczne nazwy przynajmniej kilku specyficznie egipskim fenomenom. Dziś nie wyczuwa się już zupełnie owej prześmiewczej ironii, tkwiącej w tak-

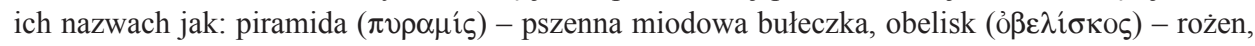
syrynga $(\sigma \hat{\nu} \rho \gamma \xi)$ - piszczałka/flet (tak Grecy nazywali groby królewskie w Tebach), krokodyl

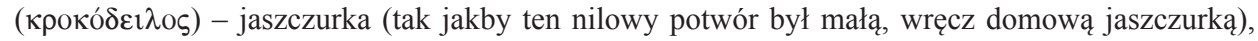
por. A. Erman, Die Religion der Ägypter: Ihr Werden und Vergehen in vier Jahrtausenden, Berlin - Leipzig 1934, 358; E. Zwolski, Świat egipski u Ajschylosa, RH 16 (1968) z. 3, 40. Przeciw ironicznej interpretacji niektórych nazw nadawanych przez Greków w Egipcie opowiedział się niedawno A. Łukaszewicz, The Greek name of pyramids, „Eos” 90 (2003) 53-55. 
fragmentach Stobajosa (V w. po Chr. ${ }^{68}$. Mimo że sam Stobajos jest twórcą z kresu późnej starożytności, to jednak nakreślony przez niego geograficzny schemat świata jest prawdopodobnie znacznie starszy.

Zgodnie z nim w centrum wszechświata leży ziemia ${ }^{69}$. Jej pozycja ma przypominać człowieka patrzącego w niebo. Tak ułożona ziemia dzieli się na części, podobnie jak to ma miejsce w przypadku segmentacji ludzkiego ciała. Ziemia patrzy w niebo, jakby patrzyła w stronę własnego ojca. Jej głowa jest zwrócona na południe, jej prawe ramię znajduje się na wschodzie, lewe na zachodzie, natomiast stopy leżą na północy. Części ciała zaś, które znajdują się między głową a stopami, zwane ogólnie środkowymi, leżą w obszarze pomiędzy południem a północą. ${ }^{70} \mathrm{~W}$ ten sposób Egipt został zlokalizowany w centrum ziemi tak, jak serce zostało umieszczone w centrum ludzkiego ciała, ponieważ serce jest siedzibą duszy. W najgorszym świetle zostały przedstawione ludy północy, gdzie zimny klimat ma korespondować z naturą mieszkańców tego regionu, których zarówno ciała, jak i umysły mają być niemal w stanie hibernacji ${ }^{71}$.

Powyższy schemat antropomorficzny, pomimo formalnego podobieństwa różni się jednak znacznie od schematu zawartego w De hebdomadibus, ponieważ jest tu wyraźnie mowa o czterech stronach świata. Ludy wschodnich, zachodnich, północnych i południowych krańców zamieszkałej ziemi nie zostały jednak wskazane imiennie. Jeśli chodzi o orientację omawianej mapy, to idąc za położeniem głowy należy wnosić, że mapa ta była zorientowana na południe. W konsekwencji schemat ten przypomina $\mathrm{w}$ dużym stopniu również zorientowany na południe „parallelogram Efora”, którego równoległoboczny schemat Ekumeny przypisuje jednak jej obrzeża konkretnym ludom. Warto przy tym pamiętać, że przedstawioną tutaj wersję ,,parallelogramu Efora” (por. rys. 1B) przekazał potomnym Egipcjanin, Kosmas Indikopleustes (VI wiek po Chr.), żeglarz i mieszkaniec Aleksandrii, dla którego również głównym punktem odniesienia mapy było południe (por. przyp. 23 i 24), podczas gdy sam Efor z Kyme (ok. 400-330 prz. Chr.) mógł zgodnie z tradycją grecką oriento-

${ }^{68}$ Por. K. Reinhardt, Poseidonios, München 1921, 380 i 382-383; A.J. Festugière, La révélation d'Hermès Trismégiste, I: L'astrologie et les sciences occultes, Paris 1944, 93; J. Mansfeld,

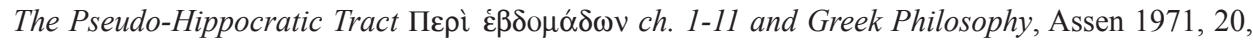
przyp. 88. Za polskie wprowadzenie do zagadnień hermetyzmu jako takiego, można uznać pracę T. Zielińskiego, Hermes Trismegistos. Studium z cyklu: Współzawodnicy chrześcijaństwa, Zamość 1920; zob. też A. Sowińska, The origins of Hermes Trismegistos and his philosophy. The theory of Tadeusz Zieliński, „Scripta Classica” 7 (2010) 85-90.

${ }^{69}$ Także i ten schemat jest szerzej analizowany w oddanym już do druku artykule: Etnomedycyna hippokratejska a geopolityczna myśl grecka w V wieku prz. Chr., por. przyp. 56.

${ }^{70}$ Por. Corpus Hermeticum/(Hermès Trismégiste), t. 4: Fragments extraits de Stobée (XXII-XXIX), texte établi et traduit A.J. Festugière; Fragments divers, texte établi par A.D. Nock, trad. par A.J. Festugière, Paris 1972², 55, 27 - 56, 8 (Fragment XXIV 11) ; zob. też tamże, s. 61-62, przyp. 31.

${ }^{71}$ Por. Corpus Hermeticum/(Hermès Trismégiste), t. 4, s. 57, 19-21 (Fragment XXIV 14) ; zob. Kochanek, Die Vorstellung vom Norden und der Eurozentrismus, s. 226-227, przyp. 234; s. 336, przyp. 43. 
wać swój ekumeniczny schemat ku północy. Z drugiej strony istnieje pewne realne podobieństwo „schematu Stobajosa" do schematu hippokratejskiego przedstawionego w De hebdomadibus. Zasadza się ono na przyznaniu głównej roli nie głowie, lecz sercu (cor) i przeponie (praecordia). W konsekwencji w roli umbilicus mundi występują odpowiednio Egipt i Jonia. „Schemat Stobajosa" zawarty w Corpus Hermeticum gloryfikuje Egipt, natomiast traktat De hebdomadibus zawarty w Corpus Hippocraticum opowiada się jednoznacznie za wyższością Hellenów nad innymi ludami Ekumeny.

„Schemat Stobajosa”, obok pewnych analogii z ,parallelogramem Efora” oraz pokrewieństwa idei z przedstawionym wyżej schematem Ekumeny, zarysowanym w piśmie De hebdomadibus, zdradza również silne związki z jednym z najważniejszych makro-schematów Ekumeny inspirowanych Biblią. Można w nim bowiem dostrzec dalekie echo najstarszego znanego dziś tekstu akrostychu imienia Adam, który to akrostych łączy cztery greckie litery tego imienia z pierwszymi greckimi literami nazw czterech stron świata ('Av $\alpha \tau 0 \lambda \dot{n}$ - wschód; $\Delta$ vi rys. 3A). Jest to fragment zachowany w III księdze Oracula Sibyllina. Tekst ten powstał w łonie hellenistycznej diaspory żydowskiej w Egipcie, w poło-

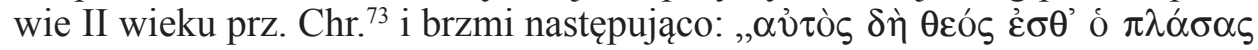

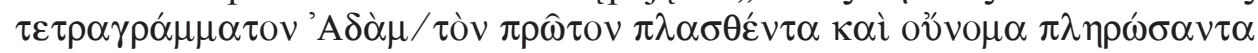

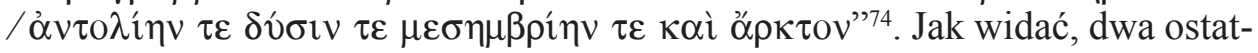
nie kierunki kardynalne zostały tutaj zacytowane w odwrotnej kolejności. W konsekwencji zamiast słowa ADAM tworzą one termin ADMA. Uważa się, że umieszczenie południa przed północą jest prawdopodobnie konsekwencją przyjęcia egipskiego punktu widzenia w geografii, gdzie podstawowa

${ }^{72}$ Istnieje kilka dość obszernych zestawień tekstów źródłowych zawierających rzeczony akrostych, por. M. Förster, Adams Erschaffung und Namengebung: Ein lateinische Fragment des s. g. slawischen Henoch, ,Archiv für Religionswissenschaft” 11 (1908) 477-529, spec. s. 478, przyp. $2-5$ i s. 515, przyp. 4; E. Turdeanu, Dieu créa l'homme de huit éléments et tira son nom des quatre coins du monde, „Revue des Études Roumaines” 13-14 (1974) 163-194, spec. s. 184-189 [repr. w: tenże, Apocryphes slaves et roumaines de l'Ancient Testament, Leiden 1981, 404-435, spec. s. 425-430]; H.L.C. Tristram, Der ,homo octipartitus” in der irischen und altenglischen Literatur, „Zeitschrift für Celtische Philologie" 34 (1975) 119-153, spec. s. 145-149; D. Cerbelaud, Le nom d'Adam et les points cardinaux: Recherches sur un thème patristique, VigCh 38 (1984) 285-301; Ch. Böttrich, Adam als Mikrokosmos: Eine Untersuchung zum slavischen Henochbuch, Frankfurt am Main 1995, 59-72. Na gruncie polskim, por. W. Berschin, Grecko-łacińskie średniowiecze. Od Hieronima do Mikołaja z Kuzy, thum. K. Liman, Gniezno 2003, 91-92 oraz 198, przyp. 4 i s. 200-201; Kochanek, Die Vorstellung vom Norden und der Eurozentrismus, s. 164-218; tenże, Gdzie leży Raj? Biblia a średniowieczny obraz świata, w: Sympozja Kazimierskie, t. 5: Miejsca święte w epoce późnego antyku, red. B. Iwaszkiewicz-Wronikowska - D. Próchniak, Lublin 2005, 116, przyp. 103; tenże, Anatole - Dysis - Arktos - Mesembria, VoxP 28 (2008) t. 52, 471-488.

${ }^{73}$ Por. Böttrich, Adam als Mikrokosmos, s. 23 i przyp. 80; zob. też Kochanek, Die Vorstellung vom Norden und der Eurozentrismus, s. 165-166.

${ }^{74}$ Oracula Sibyllina III 24-26, GCS 8, 47-48. 
oś świata odpowiadała biegowi Nilu, czyli była to oś południe-północ i taka też była przypuszczalnie orientacja map ${ }^{75}$. W tym sensie zarówno akrostych imienia Adam w wersji podanej przez cytowaną wyżej trzecią księgę Oracula Sibyllina, jak i „parallelogram Efora” w wersji Kosmasa Indikopleustesa są z sobą kompatybilne, co wynika z faktu, że oba te źródła powstały w Egipcie. Sugerują one, że geneza schematu zawartego u Stobajosa może sięgać nawet okresu hellenistycznego. „Akrostych ten pojawia się często w patrystycznych i średniowiecznych źródłach greckich, łacińskich, iryjskich, staroangielskich, starofrancuskich, słowiańskich oraz w wielu przedstawieniach graficznych i kartograficznych. W konsekwencji przyjęcia takiej interpretacji słowa Adam nie chodzi o ziemię jako taką, lecz o ziemię rozumianą jako obszar zamieszkały przez ludzi-Adamitów, czyli jako Ekumenę. Granice owej zamieszkałej Ziemi-Ekumeny nie zostały jednak sprecyzowane. Są one wszędzie tam, gdzie pojawia się człowiek-Adam" "76. Powstaje w ten sposób obraz Adama-Giganta, którego głowa jest na wschodzie, czyli w miejscu biblijnego Edenu (Rdz 2, 8), nogi zaś stanowią krańce zachodu. Natomiast jego ręce rozpięte są w stronę południa i północy. Schemat ten był niewątpliwie inspirowany omówionymi wyżej koncepcjami antropomorficznymi. Różni się jednak od nich zasadniczo tym, że powstał na bazie zakodowanego w grece akrostychu, a nie spekulacji. Akrostych ten odczytano bowiem z samej natury Ekumeny, czyli ze znanych powszechnie nazw czterech stron świata. Schematu tego nie skonstruowano więc drogą spekulacji, lecz odkryto to, co zostało ,zaszyfrowane” w Boskim dziele stworzenia. Co więcej, schemat ten nie był antropomorficzny, lecz geometryczny. Wpasowywał się bowiem dobrze zarówno w schemat koła, jak i czworoboku (najlepiej kwadratu). Ponieważ zaś odkrycia tego dokonano dzięki językowi greckiemu, odkrycie to nobilitowało ten język, ponieważ greka jawi się tutaj jako nośnik ,kodu Objawienia”. Nowej siły nadała temu starotestamentalnemu akrostychowi Pawłowa typologia Adam-Chrystus (1Kor 15, 22; por. Rz 5, 12-21). Wówczas Adama-Giganta zastępuje Chrystus-Gigant. W konsekwencji schemat ten nabrał nowego dynamicznego wyrazu, odsyłając do obrazu ramion Krzyża, który w ten sposób stał się schematem Ekumeny ${ }^{77}$. Schemat ten nawiązywał również w pewien sposób do platońskich spekulacji na temat X-kształtnej Duszy Świata ${ }^{78}$. Potwierdzają to też liczne świadectwa

${ }^{75}$ Por. Böttrich, Adam als Mikrokosmos, s. 24 i przyp. 84; zob. też, Das slavische Henochbuch, übersetzt Ch. Böttrich, Gütersloh 1995, 919, przyp. 13b; Kochanek, Anatole - Dysis - Arktos Mesembria, s. 472, przyp. 3.

${ }^{76}$ Kochanek, Anatole - Dysis - Arktos - Mesembria, s. 472.

${ }^{77}$ Por. J. Daniélou, Le signe de la croix, „La Table Ronde” 120 (1957) 38 ; zob. też Kochanek, Anatole-Dysis - Arktos - Mesembria, s. 474.

${ }^{78}$ Por. Plato, Timaeus VIII 36B-C; zob. W. Bousset, Platons Weltseele und das Kreuz Christi, ZNW 14 (1913) 273-285; H. Rahner, Griechische Mythen in christlicher Deutung, Zürich 1966², s. 58: „Was Platon im Timaios aus alter pythagoräischen Weisheit von der sich im himmlischen Chi zeigenden Weltseele schrieb, das liest nun der antike Christ wie eine schon den Heiden aufgegan- 
patrystyczne ${ }^{79}$. W ten sposób chrześcijaństwo odniosło się niejako do wcześniejszych, zarówno egipskich jak i greckich rozważań, łączących geografię z psychologią. W konsekwencji przygotowano grunt pod ideę Chrystusa Pantokratora, która zastąpiła $\mathrm{w}$ sposób niejako naturalny prastarą bliskowschodnią koncepcję šar kibrat erbettim - „,władcy czterech stron świata" Akrostych imienia Adam na swój sposób „,pogodził” geometrię i geograficzny antropomorfizm. Pewna logika schematyzacji Ekumeny zatoczywszy ogromne koło powróciła, lecz uległa w międzyczasie daleko idącej transformacji, która przystosowała ją do potrzeb ideologicznie nowego obrazu świata. Obraz ten był pod silnym wpływem Nowego Testamentu i jego teologii krzyża.

Staurologia była też prawdopodobnie silnym argumentem przemawiającym za przejęciem antycznej idei kulistości ziemi, wspartej Kratesową teorią ,pasów oceanicznych”. Można przypuszczać, że to właśnie ta ostatnia teoria była niezwykle atrakcyjna dla autorów chrześcijańskich, starających się odczytywać zakodowane w stworzonej naturze znaki Krzyża ${ }^{81}$. O ile jednak akrostych imienia Adam

gene Ahnung des weltbauenden Logos, der am Kreuz hängend den Kosmos zusammenfaßt und um das Mysterium des Kreuzes schwingen läßt”; Kochanek, Anatole - Dysis - Arktos - Mesembria, s. 474 , przyp. 12.

${ }^{79}$ Jeśli chodzi o zestawienie tych miejsc, por. Kochanek, Die Vorstellung vom Norden und der Eurozentrismus, s. 210-211, przyp. 175.

${ }^{80}$ Por. tenże, Anatole - Dysis - Arktos - Mesembria, s. 473-483.

${ }^{81}$ Odkrywanie schematu krzyża w świecie było swoistym ćwiczeniem, mającym potwierdzić prawdę ewangeliczną, por. Iustinus Martyr, Apologia I 55, 3, 7-10, PG 6, 412B; tamże I 55, 4,

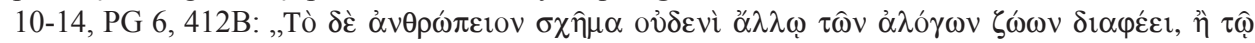

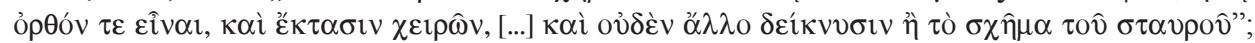
Tertullianus, Adversus Iudaeos 10, 48-49, CSEL 70, 303 lub CCL 2, 1376, 48 -49 lub PL 2, 666B: „nam et in antemna nauis, quae crucis pars est”; tenże, Adversus Marcionem III 18, CSEL 47, 407, 14-20 lub CCL 1, 532, 14-533, 20 lub SCh 399, 162, 47-54 lub PL 2, 347A: ,iam vero Moyses [...] expansis manibus orat [...], quando [...] crucis [...] erat habitus necessarius [por. Wj 17,8-13]"; tenże, Ad nationes I 12, CSEL 20, 82, 15-16 lub CCL 1, 31, 16-17 lub PL 1, 649A-B: ,si statueris hominem manibus expansis, imaginem crucis feceris"; tenże, Apologeticum 16, 7, 31-32, CSEL 69, 43 lub CCL 1, 116, 30-31 lub PL 1, 422A: „Pars crucis est omne robur, quod erecta statione defigitur”; tenże, De oratione 14, CSEL 20, 189, 12-14 lub CCL 1, 265, 6-8 lub PL 1, 1273A: „nos vero non attollimus tantum, sed etiam expandimus [manus], et dominicam passionem modulentes et orantes confitemur Christo”; tamże 29, CSEL 20, 200, 8-10 lub CCL 1, 274, 34-36 lub PL 1, 1304B: „Sed et aves tunc exurgentes eriguntur ad coelum et alarum crucem pro manibus expandunt et dicunt aliquid quod oratio videatur"; Odae Salomonis 27, 1-3; 42, 1; Minucius Felix, Octavius 29, 8, CSEL 2, 43, 10-15 lub PL 3, 346B: ,signum sane crucis naturaliter visimus in navi, cum uelis tumentibus vehitur, cum expansis palmulis labitur: et cum erigitur iugum, crucis signum est, et cum homo porrectis manibus Deum pura mente veneratur, ita signo crucis aut ratio naturalis innititur aut vestra religio formatur"; Origenes, Homiliae in Exodum III 3, 182-188 lub SCh 321, 112 lub GCS 29, 170, 19-25 lub PG 12, 316C-D: „Et vere illud impletur in nobis in quo Moyses dedit figuram: cum enim ipse elevaret manus, vincebatur Amalech [por. Wj 17,8-13]; ,[...]. Ita ergo etiam nos in virtute crucis Christi extollamus bracchia et elevamus in oratione sanctas manus [...], ut Domini mereamur auxilium”; Cyprianus, Ad Quirinum (Testimonia) II 21, CSEL 3/1, 89, 10-11 lub PL 4, 744B: „Hoc signo crucis et Amalech victus est ab Jesu per Moysen [por. Wj 17,8-13]"; Ps-Methodius, Homilia de cru- 
tworzył „krzyż ekumeniczny” (por. rys. 3A), o tyle „pasy oceaniczne” Kratesa tworzyły „krzyż wszechziemski” (por. rys. 3B). W konsekwencji powstał pewien geometryczny makro-schemat świata. Globus Kratesa doczekał się też swoistej naukowej mutacji, którą stały się (choć miało to miejsce znacznie później) tzw. „mapy strefowe” Makrobiusza (por. rys. 3C) ${ }^{82}$. Warto przy tym zwrócić uwagę

ce et passione Christi, PG 18, 400C-D: , ,

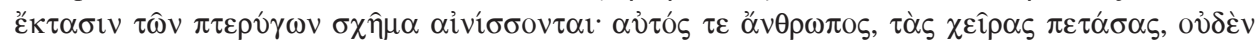

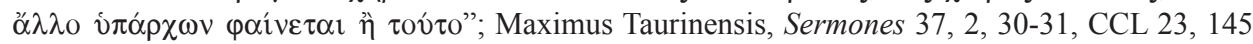
lub PL 57, 339D: „Arbor enim quaedam in navi est crux in Ecclesia”; tamże 38, 2, 19-20, CCL 23, 149 lub PL 57, 342B: „Sicut autem Ecclesia sine cruce stare non potest, ita et sine arbore navis infirma est”; tamże 38, 3, 32-34, CCL 23, 149 lub PL 57, 342C-343A: „Ipsius etiam incessus hominis, cum manus levaverit, crucem pignit; atque ideo elevatis manibus orare praecipimur, ut ipso quoque membrorum gestu passionem domini fateamur"; Ps-Hieronymus, Commentarius in Evangelium secundum Marcum 15, PL 30, 638A: „Aves, quando volant ad aethera, formam crucis assumunt; homo natans per aquas, vel orans, forma crucis vehitur. Navis per maria, antenna cruci similata sufflatur. T littera, signum salutis et crucis describitur"; Bernardus Clarae-Vallensis, Sermones in vigilia nativitatis Domini 4, 7, PL 183, 103B: „Homo [...] formam crucis habet: quam, si manus extenderit, exprimet manifestius"; Honorius Augustodunensis, Speculum Ecclesiae, PL 172, 945A: „Hominem quoque in modum crucis formavit, quia perditum per crucem reparare praedestinavit”. Przypis powyższy pochodzi z: Kochanek, Die Vorstellung vom Norden und der Eurozentrismus, s. 215-216, przyp. 193; zob. Rahner, Griechische Mythen, s. 281-328; tenże, Antenna crucis 4: Das Kreuz als Mastbaum und Antenna, ZKTh 75 (1953) 129-173; P. Yousif, Le symbolisme de la croix dans la nature chez saint Éphrem de Nisibe, w: Symposium Syriacum (13-17 IX 1976, Chantilly), OCA 205, Rome 1978, 207-227; P. Rosiński, Najwcześniejsze formy krzyża Chrystusowego, VoxP 3 (1983) z. 4, 178-179; T. Kaczmarek, Moc krzyża świętego. Uwagi z teologii III wieku, VoxP 4 (1984) z. 6-7, 166-169; S. Kobielus, Krzyż Chrystusa. Od znaku i figury do symbolu i metafory, Warszawa 2000, 165-168, L. Wojciechowski, Drzewo przenajszlachetniejsze. Problematyka Drzewa Krzyża $w$ chrześcijaństwie zachodnim (IV - pot. XVII w.). Od legend do kontrowersji wyznaniowych i piśmiennictwa specjalistycznego, Lublin 2003, 196 i 232-234 oraz ilustracje 11 i 14-18.

${ }^{82}$ Fakt ten bardzo mocno podkreśla w swych publikacjach m.in. Anna-Dorothee von den Brincken, por. taż, Mappa mundi und Chronographia. Studien zur imago mundi des abendländischen Mittelalters, „Deutsches Archiv für Erforschung des Mittelalters” 24 (1968) 134 (= taż, Studien zur Universalkartographie des Mittelalters, hrsg. Th. Szabó, Göttingen 2008, 32); taż, Die Kugelgestalt der Erde in der Kartographie des Mittelalters, „Archiv für Kulturgeschichte” 58 (1976) 85-87 (= taż, Studien zur Universalkartographie des Mittelalters, s. 194-196); taż, Raum und Zeit in der Geschichtsenzyklopädie des hohen Mittelalters, „Beiträge zur Geschichte von Stadt und Stift Essen" 96 (1981) 10-12 (= taż, Studien zur Universalkartographie des Mittelalters, s. 229-230); taż, Weltbild der lateinischen Universalhistoriker und-kartographen, w: Popoli e paesi nella cultura altomedievale (23-29 aprile 1981), t. 1, Spoleto 1983, 394-395 (= taż, Studien zur Universalkartographie des Mittelalters, s. 253); taż, Kartographische Quellen. Welt-, See- und Regionalkarten, Turnhout 1988, 33, 35 i 82; taż, Das geographische Weltbild um 1300, w: Das geographische Weltbild um 1300. Politik im Spannungsfeld von Wissen, Mythos und Fiktion, hrsg. P. Moraw, Berlin 1989, 12-13 (= taż, Studien zur Universalkartographie des Mittelalters, s. $327-$ 329); taż, Der vierte Erdteil in der Kartographie des Hochmittelalters, w: Reisen in reale und mythische Ferne. Reisenliteratur in Mittelalter und Renaissance, hrsg. P. Wunderli, Düsseldorf 1993, 1719 (= taż, Studien zur Universalkartographie des Mittelalters, s. 433-435); taż, Terrae Incognitae. Zur Umschreibung empirisch noch unerschlossener Räume in lateinischen Quellen des Mittelalters 
na to, że schemat Ekumeny był zorientowany ku wschodowi, a zatem w stronę biblijnego Raju, podczas gdy schemat globusa Kratesa z Mallos przyjmował za główny punkt odniesienia północ. Kwestia ta na gruncie stricte teologicznym może skłaniać do wielowątkowych refleksji. Tutaj jednak, czyli na gruncie historii geo- i kartografii, należy podnieść jedną, lecz prawdopodobnie zasadniczą kwestię: otóż w obu wypadkach chodzi o krzyż równoramienny. Owa równoramienność krzyża sugeruje jednakową wartość wszystkich czterech stron świata. Logika ta idzie w parze z ewangeliczną ideą rozesłania Apostołów (Mt 28, 19; Mk 16, 15; J 20, 21; Dz 1, 8; por. J 17, 18; Dz 2, 1-11), którzy mają dotrzeć do wszystkich ludzi, bez względu na miejsce ich pobytu. Krzyż równoramienny, czyli łatwy do wpisania w figury „,doskonałe”, takie jak okrąg i kwadrat, jest odzwierciedleniem wartości misji, którą mają do spełnienia posłańcy samego Boga.

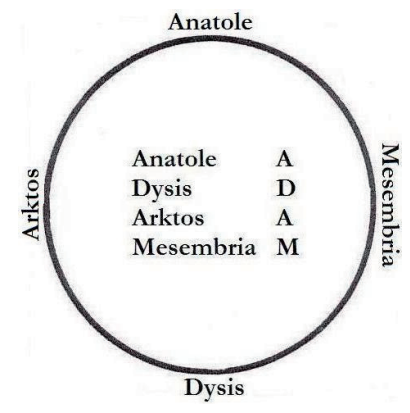

A.

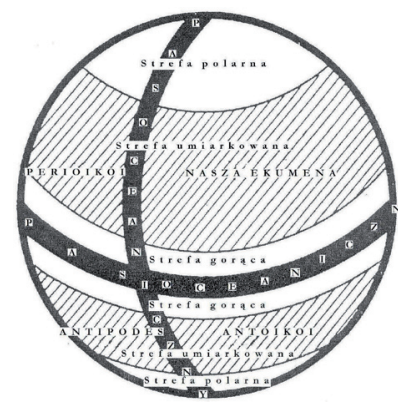

B.

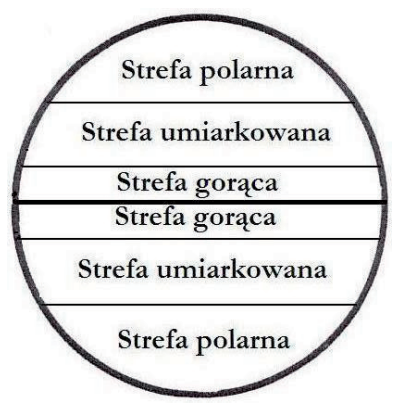

C.

Rys. 3: Podstawowe schematy chrześcijańskiej geo- i kartografii: A. Akrostych imienia Adam, B. Globus Kratesa z Mallos, C. Tzw. „mapa strefowa” Makrobiusza, upraszczająca schemat globusa Kratesa z Mallos ${ }^{83}$.

bis in die Entdeckungszeit, w: Raum und Raumverstellungen, hrsg. J.A. Aertsen - A. Speer, Berlin New York 1998, 562-563 (= taż, Studien zur Universalkartographie des Mittelalters, s. 525); taż, Das Weltbild des irischen Seefahrer-Heiligen Brendan in der Sicht des 12. Jahrhunderts, „Cartographica Helvetica” 21 (2000) 17 (= taż, Studien zur Universalkartographie des Mittelalters, s. 587).

${ }^{83}$ Pierwszy z trzech powyższych schematów (rys. 3A) jest „dziełem” autora niniejszego artykułu, por. Kochanek, Anatole - Dysis - Arktos - Mesembria, s. 471. Drugi schemat (rys. 3B) jest zmodyfikowaną przez tegoż autora (dodano napisy) wersją rekonstrukcji globusa Kratesa z Mallos, zaproponowaną swego czasu przez A.D. von den Brincken, por. taż, Die Kugelgestalt der Erde, s. 79, 
Jednak chrześcijańska koncepcja ekumeny miała swe korzenie nie tylko w źródłach antycznych i w Nowym Testamencie, lecz również w Starym Przymierzu, którego księgi inspirowały niekiedy do nieco innego postrzegania obrazu świata, niż to wyżej przedstawiono. Chodzi tutaj głównie o teksty związane z przymierzem synajskim Mojżesza, przedstawionym w Księdze Wyjścia. W tym kontekście ważne są przede wszystkim: 1) zasady konstrukcji prostokątnej Arki Przymierza (Wj 25, 10; 37, 1); 2) korespondujący z kształtem Arki prostokątny przybytek (,Namiot Spotkania”), zorientowany zgodnie z czterema stronami świata, gdzie w miejscu najświętszym miała stać arka (Wj 26, 15-37; 36, 20-34); 3) opis kwadratowego ołtarza całopalnego (wj 27, $1 ; 38,1) ; 4$ ) opis prostokątnego dziedzińca przybytku (korespondującego zarówno z kształtem przybytku, jak i samej Arki Przymierza), który był również orientowany zgodnie z czterema stronami świata (Wj 27, 9-19; 38, 9-13). Ten koncentryczny schemat znajduje swe ostateczne „domknięcie” w opisie rozmieszczenia obozujących na pustyni plemion Izraela wokół dziedzińca przybytku, podanym w Księdze Liczb (Lb 2, 3.10.18.25). Ta horyzontalna struktura znalazła swe wertykalne dopełnienie w Księdze Izajasza (Iz 40, 22c-d): „on rozciągnął niebiosa jak tkaninę i rozpiął je jak namiot mieszkalny" ${ }^{84}$. Powyższe teksty Księgi Wyjścia znajdują swe uzupełnienie w opisach świątyni. Pierwszy $\mathrm{z}$ nich odnosi się do prostokątnej budowli wzniesionej przez Salomona $(1 \mathrm{Krl}$ 6, 2-38), drugi natomiast do wizji przyszłej świątyni z Księgi Ezechiela, która zawiera zarówno ideę geometryzacji przestrzeni, jak i orientacji zgodnej z czterema stronami świata, a istotą tego założenia architektonicznego jest koncentryczny plan całości (Ez 40, 1-44, 3). Z tej też perspektywy należy rozpatrywać pierwsze chrześcijańskie schematy geograficzne sensu stricto, związane z imionami trzech autorów działających w II wieku: Teofila z Antiochii († 182), Tacjana (ok. 130-193) i Ireneusza z Lyonu (ok. 140-202).

Teofil, będąc zdecydowanym przeciwnikiem idei kulistości ziemi ${ }^{85}$, wyszedł od wspomnianego już wersu Księgi Izajasza (40, 22), który pozwalał na

rys. 1 (= taż, Studien zur Universalkartographie des Mittelalters, s. 188); taż, Das geographische Weltbild um 1300, s. 13, rys. 1 (= taż, Studien zur Universalkartographie des Mittelalters, s. 328, rys. 1); taż, Der vierte Erdteil , s. 18, rys. 1 (= taż, Studien zur Universalkartographie des Mittelalters, s. 434, rys. 1); taż, Terrae Incognitae, s. 559, rys. 1 (= taż, Studien zur Universalkartographie des Mittelalters, s. 521). Również tzw. „mapa strefowa” Makrobiusza (rys. 3C) jest inspirowana schematem niemieckiej badaczki, por. taż, Mappa mundi und Chronographia, s. 134 (= taż, Studien zur Universalkartographie des Mittelalters, s. 32); taż, Die Kugelgestalt der Erde, s. 86, rys. 2 (= taż, Studien zur Universalkartographie des Mittelalters, s. 195); taż, Das geographische Weltbild um 1300, s. 13, rys. 2 (= taż, Studien zur Universalkartographie des Mittelalters, s. 328, rys. 2); taż, Der vierte Erdteil, s. 19, rys. 2 (= taż, Studien zur Universalkartographie des Mittelalters, s. 434, rys. 2); taż, Terrae Incognitae, s. 563, rys. 2 (= taż, Studien zur Universalkartographie des Mittelalters, s. 525).

${ }^{84}$ Polski przekład za: Biblia Tysiąclecia, Poznań $1980^{3}$.

${ }^{85}$ Por. Theophilus Antiochenus, Ad Autolycum II 32, SCh 20, 182 lub PG 6, 1105B, thum. L. Misiarczyk, BOK 24, 430-431. 
stworzenie prostego schematu universum, przedstawiając go w formie namiotu o podstawie prostokąta, co sugerowało podobieństwo do Mojżeszowego „Namiotu Spotkania” i tak też rzecz starał się przedstawić Antiocheńczyk ${ }^{86}$. $\mathrm{W}$ ten sposób nad prostokątną Ekumeną rozciągało się prostokątne niebo. Schemat, przywodzący na myśl ,parallelogram Efora” (por. rys. 1B) ${ }^{87}$, stawał się prosty i łatwy do zapamiętania. Następny element swego schematu zaczerpnął Teofil z opisu budowy wieży Babel (Rdz 11, 1-9), czyli z perykopy wyjaśniającej przyczyny rozproszenia i wielości ludów oraz różnorodności języków. W jego opinii ludzie opuszczając Babel udali się początkowo w trzech kierunkach: na wschód, na południe i na zachód, a dopiero później na północ $^{88}$. Takie postawienia sprawy przypomina z kolei tezę Herodota, w myśl której Scytowie mieli być najmłodszym ludem Ekumeny ${ }^{89}$. W konsekwencji schematyzacja Teofila zawierała zarówno elementy biblijne, jak i nawiązania do powszechnie w jego epoce znanych, dawnych schematów greckich, co ułatwiało zapewne zrozumienie biblijnego obrazu świata chrześcijanom, nie pochodzącym z kręgu judaizmu.

Wizja kształtu Ekumeny Tacjana Syryjczyka jest w porównaniu ze schematem Teofila jeszcze bardziej uproszczona. Jego zamieszkała ziemia miała kształt kwadratu, co jednoznacznie sugerowało biblijną ideę centrum i peryferii ${ }^{90}$.

Za autorytetem tekstów związanych z przymierzem synajskim Mojżesza szedł także Ireneusz z Lyonu przedstawiając, podobnie jak Teofil z Antiochii, schemat Ekumeny w formie prostokąta ${ }^{91}$.

Prostota tych trzech schematów staje się lepiej zrozumiała, jeśli weźmie się pod uwagę ich, jakby dziś powiedziano, kontekst duszpasterski. Wspomniani autorzy nie mieli bowiem na celu wgłębiania się w meandry współczesnej im geo- i kartografii, ale ich troską było głoszenie Ewangelii, zgodnie z ostatnim nakazem Chrystusa, zawartym w cytowanej wyżej formule tzw. rozesłania Apostołów. Ekumena jest tu tylko miejscem akcji. Ponieważ jednak Biblia sugeruje pewien obraz świata, jej propagatorzy nie mogli go pomijać w swych teologicznych rozważaniach.

\footnotetext{
${ }^{86}$ Por. tamże II 13, SCh 20, 132-134 lub PG 6, 1073A, BOK 24, 411-412.

${ }^{87}$ Schemat geograficzny Teofila zrekonstruował Robert Grant (Patristica, s. 227).

${ }^{88}$ Por. Theophilus Antiochenus, Ad Autolycum II 32, SCh 20, 182 lub PG 6, 1105A-B, BOK 24, 431.

${ }^{89}$ Por. Herodotus, Historia IV 5.

${ }^{90}$ Por. Tatianus, Oratio ad Graecos 20, PG 6, 852B, lub ed. M. Whittaker: Oratio ad Graecos and Fragments, Oxford 1982, 40, 24-29, thum. L. Misiarczyk, BOK 24, 334. Również schemat Tacjanowego obrazu świata zrekonstruował R. Grant (Patristica, s. 226); zob. Wolska, Geographie, szp. 183.

${ }^{91}$ Por. Irenaeus Lugdunensis, Adversus haereses I 10, 2, SCh 264, s. 159-160 lub PG 7, 552B553A; tamże, III 11, 8, SCh 211, 161-162; zob. Grant, Patristica, s. 226 (znajduje się tu rekonstrukcja Ireneuszowego obrazu Ekumeny).
} 


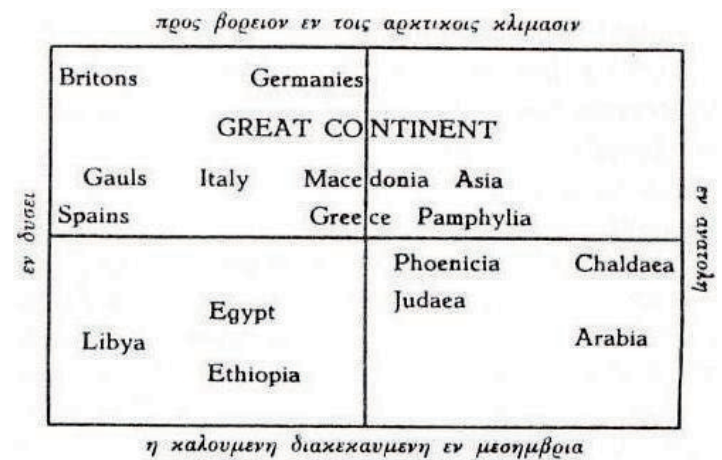

A.

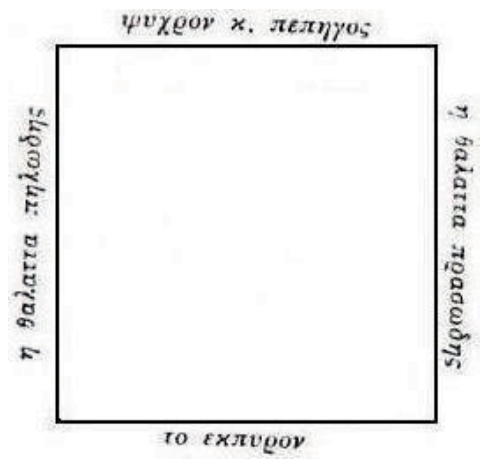

B.

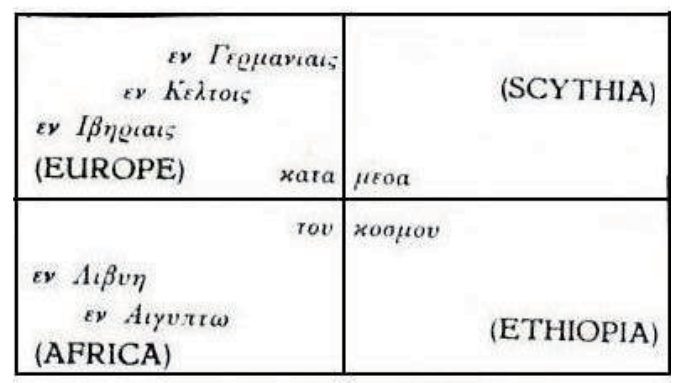

C.

Rys. 4: A. Schemat Ireneusza z Lyonu (por. przyp. 91); B. Schemat Teofila z Antiochii (por. przyp. 87); C. Schemat Tacjana Syryjczyka (por.przyp. 90).

Na gruncie powyższych założeń stał również Orygenes (185-254). W swym komentarzu do Księgi Wyjścia Aleksandryjczyk widział schemat świata w opisie dopiero co przywołanego Mojżeszowego Namiotu Spotkania i stwierdził jednoznacznie, że ,tabernaculum hoc totius mundi tenet figuram"92. Egzegeta aleksandryjski miał na tym polu znakomitego poprzednika w osobie Filona Aleksandryjskiego (ok. 15 p.n.e.-50 n.e.). Do tego ostatniego nawiązywał też Józef Flawiusz (ok. 37-ok. 100 po Chr.). Wypowiadał się w tym względzie również wspomniany już Teofil Antiocheński oraz Klemens Aleksandryjski (zm. ok. 215 n.e.). Później zaś zabierali głos w tej materii m.in. czołowi egzegeci szkoły antiocheńskiej: Diodor z Tarsu (zm. ok. 394 n.e.), Teodor z Mopsuestii (ok. 352-428 n.e.) i Teodoret z Cyru (ok. 393-ok. 466 n.e.). Ślady koncepcji Filona widoczne są także u PseudoChryzostoma (V w. $)^{93}$.Niewątpliwą zasługą Orygenesa było jednak to, że poprzez swą egzegezę pogłębił symbolikę teologiczną biblijnego obrazu świata.

${ }_{92}$ Por. Origenes, In Exodum hom. 9, 4, 3-4, SCh 321, 294 lub GCS 29, 240, $23-24$ lub PG 12, 366A, thum. S. Kalinkowski, PSP 31/1, 244-246.

${ }^{93}$ Por. Philo Alexandrinus, De monarchia II 1; tenże, De opificio mundi 2 i 10; tenże, De vita 
Do rozważań wzorowanych na Teofilu Antiocheńskim powrócił w kilka wieków później wspomniany już Kosmas Indikopleustes, który również odwołał się do tekstu Księgi Izajasza $(40,22)^{94}$. Także on nawiązał do idei Mojżeszowego „Namiotu Spotkania”95, lecz odniesienie to stanowiło dla niego swoisty wątek pomocniczy. Schemat Kosmasa, mimo że autor poświęcił mu w zasadzie dzieło swego życia, czyli napisany około roku 550 traktat Topographia Christana ${ }^{96}$, nie stał się znaczącym schematem universum w żadnym kręgu cywilizacji chrześcijańskie, z wyjątkiem Rosji ${ }^{97}$.

Moysis II 82. 101; Iosephus Flavius, Antiquitates Iudaicae III 6, 4, 123; tamże III 7, 7, 181, thum. Z. Kubiak: Józef Flawiusz, Dawne dzieje Izraela, Poznań 1962, 193-194 i 199; Clemens Alexandrinus, Stromata V 6, 33, 2, GCS 15(52), 347, 14-18 lub SCh 278, 78, lub PG 9, 57A; tamże V 6, 34, 7, GCS 15(52), 348, 20-349, 1 lub SCh 278, 80 lub PG 9, 60A, thum. J. Niemirska-Pliszczyńska: Klemens Aleksandryjski, Kobierce zapisków filozoficznych dotyczacych prawdziwej wiedzy, t. 2, Warszawa 1994, 30 i 31; Diodorus Tharsensis, Contra fatum, w: Photius, Bibliotheca 223, PG 103, 872B, thum. O. Jurewicz: Focjusz, Biblioteka, t. 3: Kodeksy 223-237, Warszawa 1988, 33; R. Devreesse, Essai sur Théodore de Mopsueste, Studi e Testi 141, Città del Vaticano 1948, 26, n. 1; Théodore de Mopsueste, Les homélies catéchétiques, Reproduction phototypique du ms. Mingana Syr. 561 (Selly Oak Colledes' Library, Birmingham), traduction, introduction, index par Raymond Tonneau en collaboration avec R. Devreesse, Città del Vaticano, Biblioteca Apostolica Vaticana, 1949 (Studi e Testi, 145), s. 326 (= fol $82^{v}$ : fotokopia tekstu syryjskiego) = s. 327 (przekład francuski); Theodoretus Cyrensis, Quaestiones in Exodum, 60, PG 80, 281A i 281D-284A; tenże, Interpretatio Epistulae ad Hebraeos 8, PG 82, 737D; Ps-Chrysostomus, In laudem conceptionis sancti Ioannis prophetae, praecursoris et baptistae, PG 50, 787-788. Kwestię symboliki „Namiotu Spotkania” oraz związanej z nią schematyzacji „universum” analizuje szerzej Wanda Wolska, por. taż, La Topographie Chrétienne de Cosmas Indicopleustès, s. 41, 113-118, 131, 136 i 150.

${ }^{94}$ Cosmas Indicopleustes, Topographia Christiana II 9, 21-24, SCh 141, 315 lub PG 88, 77B; II 17, 8-9, SCh 141, 321 lub PG 88, 81A; IV 4, 2-3, SCh 141, 539 lub PG 88, 184B; VII 84, 1-3, SCh 197 , 147 lub PG 88, 380D; VIII 20, 9-10, SCh 197, 191 lub PG 88, 396C; VIII 24, 5, SCh 197, 195 lub PG 88, 397C; X 31, 3-4, SCh 197, 269 lub PG 88, 424A; XII 13, 2, SCh 197, 375 lub PG 88, 457D.

${ }^{95}$ Por. tamże (Prologus secundus) 6, 5-16, SCh 141, 267-269 lub PG 88, 56C-D; II 19, 1-8, SCh 141, 323 lub PG 88, 81B; II 35, 1-4, SCh 141, 341 lub PG 88, 89D-92A; II 48, 1-16, SCh 141, 357 lub PG 88, 97C; V 20, 1-3, SCh 159, 39 lub PG 88, 201A.

${ }^{96} \mathrm{~W}$ aspekcie stricte geograficznym dzieło Kosmasa było kilkakrotnie już przedmiotem niekiedy nawet obszernych publikacji monograficznych, por. G.L. Bertolini, Su la cosmografia di Cosma Indicopleustes, „Bollettino della Società Geografica Italiana” 48 (1911) 1455-1497; H. Winter, Die Weltkarte des Kosmas Indikopleustes, 535-547 AD, „Die Erde” 86 (1955) 63-68; B. Schleißheimer, Kosmas Indikopleustes ein altchristliches Weltbild, München 1959; Wolska, La Topographie Chrétienne de Cosmas Indicopleustès, passim; taż, La „Topographie chrétienne” de Cosmas Indicopleustès: hypothèses sur quelques thèmes de son illustration, REB 48 (1990) 155-191; M. Kominko, The world of Cosmas: universe described and depicted in byzantine manuscripts of the Christian Topography, Oxford 2006 [non vidi]; zob. też K. Kitamura, Cosmas Indicopleustès et la figure de la terre, w: Moïse géographie - Recherches sur les représentations juives et chrétiennes de l'espace, éd. A. Desreumaux - F. Schmidt, Paris 1988, 79-98; M. Kominko, The map of Cosmas, the Albi map, and the tradition of ancient geography, „Mediterranean Historical Review” 20 (2005) 163-186 [non vidi].

${ }^{97}$ Por. Wolska, La Topographie Chrétienne de Cosmas Indicopleustès, s. 183 i przyp. 1; N. Ross, L'image du monde physique en Russie à la fin du XIVE siècle, „Cahiers du Monde Russe et 

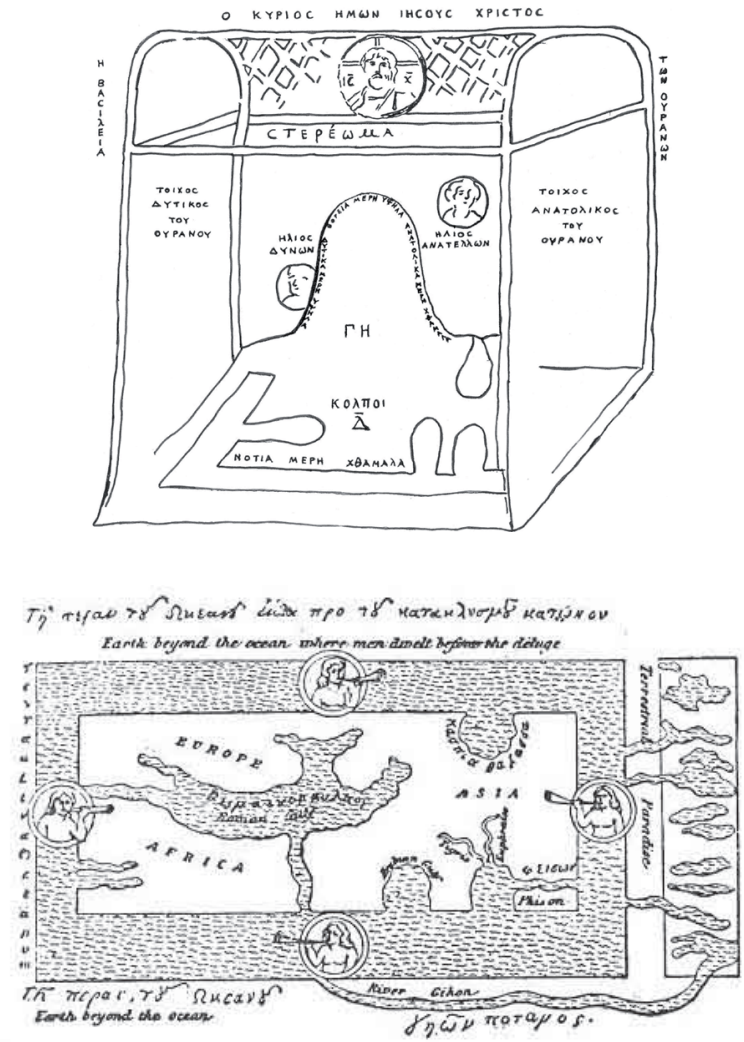

Rys. 5: Przerysy schematu Ekumeny Kosmasa Indikopleustesa ${ }^{98}$.

Innym rodzajem patrystycznego schematu Ekumeny jest tzw. mapa typu T-O. Jej genezy należy szukać z jednej strony w Księdze Rodzaju, a dokładniej w tzw. „Tablicy Narodów” (Rdz 10), z drugiej zaś w dziele Herodota. On to bowiem zastanawiał się nad kwestią granic między trzema znanymi wówczas kontynentami i nad zagadnieniem ich wzajemnych proporcji. W tym względzie „Ojciec historii” uważał, że Europa obejmuje całą północną połać Ekumeny, zaś południowa jej cześć dzieli się między Azję i Libię (= Afrykę), przyjmując Nil za ich linię demarkacyjną. Europa były więc dwa razy większa niż Azja i Libia (= Afryka)

Soviétique" 15 (1974) 246 i 255; A. Jakobs, Kosmas Indikopleustes. Die christliche Topographie in slavischer Übersetzung, „Byzantinoslavica” 40 (1979) 184 i 192: E.K. Piotrovskaja, On the Old Russian version of „Christian Topography” by Cosmas Indicopleustes, JÖB 32/4 (1982) 147-153.

${ }_{98}$ Przerysy te pochodzą odpowiednio z: Wolska, La „Topographie chrétienne” de Cosmas Indicopleustès: hypothèses sur quelques thèmes, s. 159, rys. 3 i s. 162, rys. 5. Oryginały zawiera kodeks Sinaïticus Graecus 1186, fol. $69^{\mathrm{r}}$ i $66^{\mathrm{v}}$. 
razem wzięte ${ }^{99}$. $Z$ biegiem czasu proporcje te zmieniły się na korzyść Azji. Jednak dopiero Augustyn (354-430) odwrócił jednoznacznie proporcje rzeczonych kontynentów; odtąd Azja jest dwa razy większa niż Europa i Afryka razem wzięte ${ }^{100}$. Te trzy kontynenty zostały też definitywnie wpisane w okrąg (orbis), czyli figurę doskonałą, ponieważ tylko taki świat mógł wyjść spod ręki Stwórcy. Granicą między Azją a Afryką pozostaje Nil, rzeką zaś graniczną Azji i Europy stał się ostatecznie Tanais, identyfikowany z dzisiejszym Donem ${ }^{101}$. Natomiast Morze

\author{
${ }^{99}$ Herodotus, Historia IV 42 i 45. \\ ${ }^{100}$ Por. Augustinus, De civitate Dei XVI 17, CSEL 40/2, 159, 7-12 lub CCL 48, 521, 12-17
} lub PL 41, 497, thum. W. Kornatowski: Św. Augustyn, O państwie Bożym, t. 2, Warszawa 1977, 237; zob. Orosius, Historiae adverus paganos I 2, 2-3, CSEL 5, 9, 5-10, 1 lub PL 31, 672B-673A; Isidorus Hispalensis, Etymologiae XIV 2, 3, PL 82, 496B; Beda Venerabilis, De natura rerum 51, 6, CCL 123A, 234 lub PL 90, 276B; Rabanus Maurus, De universo 12, 2, PL 111, 333C-D; Willelmus Calculus, Gesta Normannorum Ducum, ed. E.M.C. van Houts, vol. 1, Oxford 1992, 12 (I 2) lub PL 149, 782A; Cosmas Pragensis, Chronica Boemorum, I 2, MGH SRG N.S. II, s. 5, 12-14 lub MGH SS VI, s. 32, 43-33, 1 lub PL 166, 58B; Willelmus de Conches, De philosophia mundi IV 4, PL 172, 86D lub PL 90, 1168D-1169A; Hugo de Sancto Victore, Priorum excerptionum libri decem III 1, PL 177, 209D. Ideę augustyńskich proporcji Azji do Europy i Afryki jako 2:1:1 rozpropagowała A.D. von den Brincken, por. taż, Europa in der Kartographie des Mittelalters, „Archiv für Kulturgeschichte” 55 (1973) 295 (= taż, Studien zur Universalkartographie des Mittelalters, s. 155); taż, Ost- und Südosteuropa in der abendländischen Kartographie des Spätmittelalters, „Revue des Études SudEst Européennes” 13 (1975) nr 2, 253 (= taż, Studien zur Universalkartographie des Mittelalters, s. 179); taż, Die Kugelgestalt der Erde, s. 87-88 (= taż, Studien zur Universalkartographie des Mittelalters, s. 197); taż, Weltbild der lateinischen Universalhistoriker, s. 396 (= taż, Studien zur Universalkartographie des Mittelalters, s. 254); taż, Bulgarien im allgemeinen Geschichtsbewußtsein des Abendlandes im Mittelalter, „Mitteilungen des Bulgarischen Forschungsinstituts in Österreich” 9 (1987) Heft 1, 93 (= taż, Studien zur Universalkartographie des Mittelalters, s. 305); taż, Gyrus und Spera - Relikte griechischer Geographie im Weltbild der Frühscholastik, „Sudhoffs Archiv” 73 (1989) Heft 2, 133 (= taż, Studien zur Universalkartographie des Mittelalters, s. 351); taż, Der vierte Erdteil, s. 19-20 (= taż, Studien zur Universalkartographie des Mittelalters, s. 435); taż, Köln, das Reich und die Ökumene (800-1475), w: Köln, Stadt und Bistum in Kirche und Reich des Mittelalters. Festschrift für Odilo Engels zum 65. Geburtstag, hrsg. H. Vollrath - S. Weinfurter, Köln 1993, 715-716 (= taż, Studien zur Universalkartographie des Mittelalters, s. 458); taż, Kosmographische Betrachtungen bei den Kirchenvätern, auf mittelalterlichen Mönchskarten und bei Gerhard Mercator, w: Mercator und seine Welt, hrsg. R. Vermij, Duisburg 1997, 33 i 37 (= taż, Studien zur Universalkartographie des Mittelalters, s. 501 i 504); taż, Terrae Incognitae, s. 563 (= taż, Studien zur Universalkartographie des Mittelalters, s. 526); taż, Roma nella cartografia medievale (secoli IX-XIII), w: Roma antica nel Medioevo. Mito, rappresentazione, sopravvivenza nella „Respublica Christiana” dei secoli IX-XIII. Atti della quattordicesima Settimana internazionale di studio (Mendola, 24-28 agosto 1998), Milano 2001, 213 (= taż, Studien zur Universalkartographie des Mittelalters, s. 596); taż, Herausragende Plätze der antiken Geschichte im Bild der mittelalterlichen Ökumene-Karte (9. bis beginnendes 14. Jahrhundert), w: Geschichtsdeutung auf alten Karten. Archäologie und Geschichte, hrsg. D. Unverhau, Wiesbaden 2003, 25 (= taż, Studien zur Universalkartographie des Mittelalters, s. 649).

${ }^{101}$ Taka opcja istniała już w klasycznej starożytności greckiej. Wspomina o niej Herodot (Historia IV 45). W następnych wiekach zarówno Grecy, jak i Rzymianie uważali Tanais za naturalną granicę między Europą i Azją, por. A. Herrmann, Tanais, RE 2. Reihe, IV/2, Stuttgart 
Śródziemne to linia demarkacyjna między Europą a Afryką. Ponieważ powstała w ten sposób mapa typu T-O (por. rys. 8C) jest zorientowana na wschód, łatwo zauważyć, że granice kontynentów tworzą krzyż w kształcie litery Tau, co było prawdopodobnie głównym celem Augustyna przy konstrukcji tego schematu ${ }^{102}$. Przypuszczalnie też właśnie temu, schemat ten zawdzięczał swą wręcz zawrotną karierę i to zarówno w literaturze patrystycznej, jak i średniowiecznej, podobnie jak akrostych imienia Adam. W ten bowiem sposób po raz wtóry został odkryty znak krzyża zakodowany w samej strukturze Ekumeny. Można wręcz zaryzykować tezę, że tak rozumiana Ekumena jawiła się chrześcijanom doby patrystycznej jako ziemia, która ze swej istoty jest ziemią świętą, czy też ziemią wybraną, leżącą w cieniu Krzyża. Motyw wybraństwa w cieniu Krzyża to motyw podkreślający ogrom trudu, jaki to wybraństwo z sobą niesie. Krzyż ten wyznaczał jednocześnie granice pomiędzy potomkami Jafetyta (Europa), Sema (Azja) i Chama (Afryka), schematyzując ostatecznie Noachicki diamerismos ${ }^{103}$ Ekumeny, naszkicowany we wspomnianej wyżej „Tablicy Narodów” (Rdz 10).

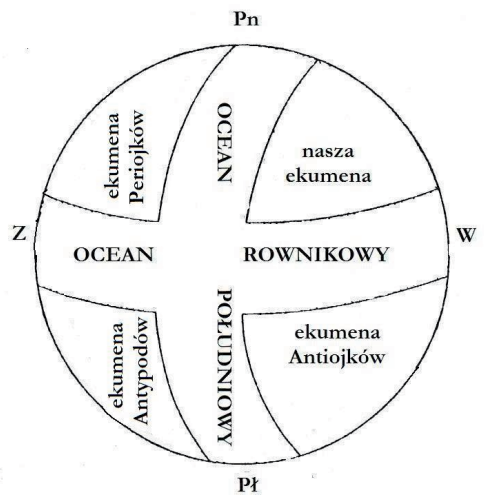

A.

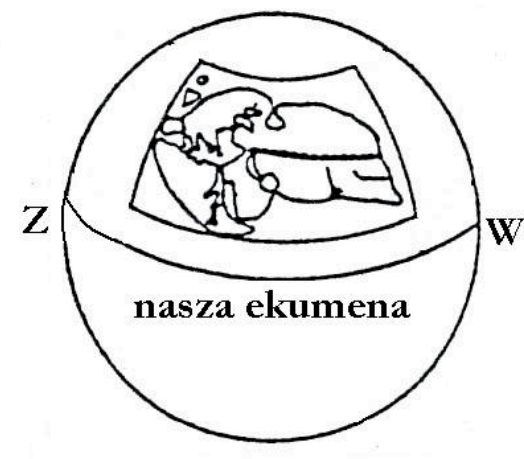

B.

1932, 2165, 34 - 2166, 35; J. Kowalski, Quaestiones hydrographicae, Kraków 1934, 209; G. Aujac, Strabon et la science de son temps, Paris 1966, 275; R. Dion, Où Pythéas voulait-il aller?, w: Mélanges d'archéologie et d'histoire offerts à André Piganiol, éd. R. Chevalier, t. 3, Paris 1966, 1319-1320 i 1331; tenże, La géographie d'Homère inspiratrice de grands desseins impériaux, BAGB 1973, nr 4, 468-469.

${ }^{102}$ Por. Kochanek, Die Vorstellung vom Norden und der Eurozentrismus, s. 213-216.

${ }^{103}$ Por. tamże, s. 233-243; zob. też Wolska, Geographie, szp. 214-216; E. Caire, Le diamérismos selon Jean Malalas, w: Recherches sur la Chronique de Jean Malalas, vol. 1, éd. J. Beaucamp, Paris 2004, 19-36; O. Andrei, Spazio geografico, etnografia ed evangelizzazione nella Synagoge di Ippolito, ZACh 11 (2007) Heft 2, 221-278. 


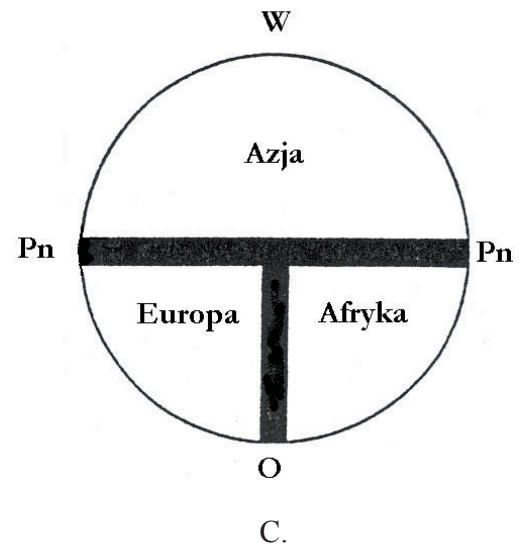

Rys. 6: Hipotetyczny proces genezy Augustyńskiego schematu mapy T-O: A. globus Kratesa z Mallos (por. rys. 3C i przyp. 86), B. „nasza” Ekumena wg. Strabona ${ }^{104}$, C model Augustyna ${ }^{105}$.

Staurocentryczny schemat Ekumeny i kuli ziemskiej jako takiej stał się schematem przewodnim geo- i kartografii następnych stuleci. Staurocentryzm łączył się przy tym nierozerwalnie z chrystocentryzmem. Schematy te nie były zatem właściwie wyobrażeniami z dziedziny kartografii, lecz podobnie jak np. znak ryby stanowiły swoiste chrześcijańskie wyznanie wiary. Widać tutaj wyraźnie silne piętno teologii Nowego Testamentu. Obok, niejako na drugim planie, widoczne są w patrystycznym obrazie Ekumeny inspiracje starotestamentalne. Ich źródłem jest 10 rozdział Księgi Rodzaju oraz teksty związane z przymierzem synajskim Mojżesza, przedstawionym w Księdze Wyjścia, wśród których główną rolę odgrywał opis „Namiotu Spotkania”. Ten biblijny wątek został oparty na klasycznej, starogreckiej osnowie. W ten sposób dobrze znane schematy nabrały nowej treści i zostały wprzęgnięte w służbę nowej ideologii. Były przy tym, dzięki odwołaniu się do najprostszych figur geometrycznych, łatwe do zapamiętania, a zatem użyteczne w patrystycznej katechezie i homiletyce, jak również w ówczesnej szkole.

${ }^{104}$ Parallelogram Strabona (rys. 8B) jest nieznacznie zmodyfikowanym schematem, który znajduje się m.in. w: И.П. Магидович, Очерки по истории географических открытий, I, Москва 1949, 45, rys. 5 (= J.P. Magidowicz, Zarys historii odkryć geograficznych, thum. I Gieysztor, Warszawa 1952, 71, rys. 5); Wolska, La Topographie Chrétienne de Cosmas Indicopleustès, s. 248, rys. 13; G. Aujac, La géographie dans le monde antique, Paris 1975, 67, rys. 13; Sirko, Zarys historii kartografii, s. 22, rys. 6.

${ }^{105}$ Przedstawiony wyżej augustyński schemat Ekumeny z wyeksponowaniem „Tau” jest inspirowany podobnym rysunkiem A.D. von den Brincken: Die Kugelgestalt der Erde, s. 88, rys. 3 (= taż, Studien zur Universalkartographie des Mittelalters, s. 198); taż, Das geographische Weltbild um 1300, s. 14, rys. 4 (= taż, Studien zur Universalkartographie des Mittelalters, s. 330, rys. 4); taż, Der vierte Erdteil, s. 20, rys. 3 (= taż, Studien zur Universalkartographie des Mittelalters, s. 436, rys. 3); taż, Terrae Incognitae, s. 563, rys. 3 (= taż, Studien zur Universalkartographie des Mittelalters, s. 525). 
DIE SCHEMATA DER ÖKUMENE IN DER PATRISTISCHEN LITERATUR IM ZUSAMMENHANG MIT DEN KLASSISCHEN SCHEMATA DER BEWOHNTEN ERDE

\section{(Zusammenfassung)}

Dieser Aufsatz stellt einen Versuch dar, die wichtigsten Schemata der Erde und der Ökumene (der besiedelte Teil der Erdoberfläche) in der antiken und patristischen Geografie und Kartografie zusammenzutragen. Ausgangspunkt waren solche Begriffe wie: $\gamma \varepsilon \omega-\mu \varepsilon \tau \rho i \alpha, \gamma \varepsilon \omega-\gamma \rho \alpha \varphi i \alpha, \chi \omega \rho o-\gamma \rho \alpha \varphi^{\prime} \alpha$ und $\tau$ o $\alpha$ o- $\gamma \rho \alpha \varphi i \alpha$. Die Verben $\mu \varepsilon \tau \rho \varepsilon ́ \omega$ und $\gamma \rho \alpha ́ \varphi \omega$ beschreiben die zwei Hauptarten der Erderforschung $(\Gamma \hat{\eta})$ durch altertümliche und patristische Autoren: die Bemessungen der Erde im Rahmen der $\gamma \varepsilon \omega-\mu \varepsilon \tau \rho i ́ \alpha$ und die Beschreibung der Erde im Rahmen der $\gamma \varepsilon \omega-$

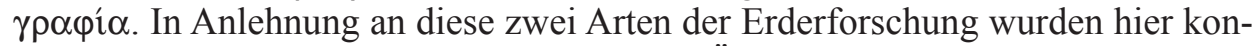
sequenterweise auch die Hauptschemata der Ökumene in zwei Arten gegliedert: in das geometrische und in das geografische Schema.

$\mathrm{Zu}$ den wichtigsten geometrischen Schemata der Erde und der Ökumene in der antiken Geographie gehören der Kreis, das Parallelogramm, der Globus, das Trapez, die Raute und Sphendone. Begriffe, die geometrische Schemata beschreiben, sind also solche schematisierende Begriffe wie: $\sigma \tau \rho \circ \gamma \gamma v ́ \lambda \eta, \kappa v \lambda \iota v \delta \rho o \varepsilon เ \delta \eta ́ s$,

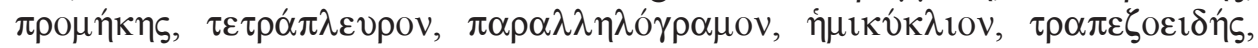

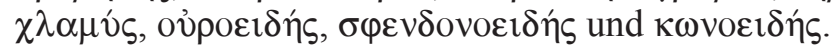

$\mathrm{Zu}$ den wichtigsten geographischen Schemata der Ökumene im Altertum gehört ein anthropomorphisches Schema, das sich in der hippokratischen Schrift Über die Hebdomadenlehre befindet. In diesem Text zerfällt also die ganze Erde in 7 Teile: 1) sie hat den Peloponnes als Kopf und Gesicht, 2) den korinthischen Isthmus als Rückenmark oder Hals, 3) Jonien als Zwerchfell, 4) den Hellespontos als Schenkel, 5) den thrakischen und kimmerischen Bosporos als Füße, 6) Ägypten und das ägyptische Meer als Bauch, 7) das Schwarze Meer und die Maiotische See als unteren Bauch und Mastdarm.

Diese antiken geometrischen Hauptschemata der Erde und der Ökumene in Verbindung mit der Völkertafel von Gen 10, 1-32, die die unter die drei Söhne Noahs geteilte Welt schildert, mit der Beschreibung des Offenbarungszeltes (Ex 26, 15-37; 36, 20-34), mit der Darstellung vom Vorhof des Offenbarungszeltes (Ex 27, 9-19; 38, 9-13) und mit der Beschreibung der Ordnung im Lager der Israeliten, die rings um das Offenbarungszelt lagern sollten (Num 2, 3. 10. 18. 25), wurden die Grundlage der patristischen geometrischen Schemata der Erde an sich und der besiedelten Welt.

Das oben erwähnte anthropomorphische Schema wurde wahrscheinlich hingegen (mutatis mutandis) eine ferne Inspirationsquelle für das gut bekannte Akrostichon des Namens Adam, wo die ersten Buchstaben der griechischen Bezeichnungen für die vier Himmelsrichtungen den Namen des Urvaters der

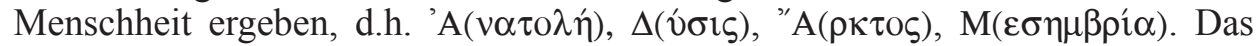
Akrostichon wurde das patristische Hauptschema der Welt. Dieses Schema, dem 
die Typologie Adam-Christus (1 Kor 15, 22; Röm 5, 12-21) zugrunde lag, stellte die christozentrisch-anthropologische Perspektive des Christentums gut dar.

Die patristischen Schemata waren eigentlich keine Vorstellungen aus dem Bereich der Kartografie sensu stricto, sondern stellten, ähnlich wie zum Beispiel das Zeichen „Fisch”, ein bestimmtes christliches Glaubensbekenntnis dar. Man sieht hier deutlich den Einfluss der Theologie des Neuen Testaments. Daneben, irgendwie im Hintergrund, sind in dem patristischen Bild der Ökumene alttestamentarische Inspirationen sichtbar. Diese biblischen Elemente waren an die klassische altgriechische Begriffsstruktur aus dem Bereich der Geo- und Kartografie angelehnt. Auf dieses Art erhielten die gut bekannten Schemata einen neuen Inhalt und wurden in den Dienst der neuen Ideologie eingespannt. Darüber hinaus waren sie dank der Bezugnahme auf die einfachsten geometrischen Figuren leicht zu merken und somit in der patristischen Katechese und in der Homiletik sowie auch im damaligen Schulunterricht gut anwendbar. 